This item was submitted to Loughborough's Research Repository by the author.

Items in Figshare are protected by copyright, with all rights reserved, unless otherwise indicated.

\title{
Did the market signal impending problems at Northern Rock? An analysis of four financial instruments
}

PLEASE CITE THE PUBLISHED VERSION

\section{PUBLISHER}

(c) Loughborough University

\section{VERSION}

VoR (Version of Record)

\section{LICENCE}

CC BY-NC-ND 4.0

\section{REPOSITORY RECORD}

Hamalainen, Paul, Adrian Pop, Maximilian J.B. Hall, and Barry Howcroft. 2019. "Did the Market Signal Impending Problems at Northern Rock? an Analysis of Four Financial Instruments". figshare. https://hdl.handle.net/2134/4203. 
This item was submitted to Loughborough's Institutional Repository (https://dspace.lboro.ac.uk/) by the author and is made available under the following Creative Commons Licence conditions.

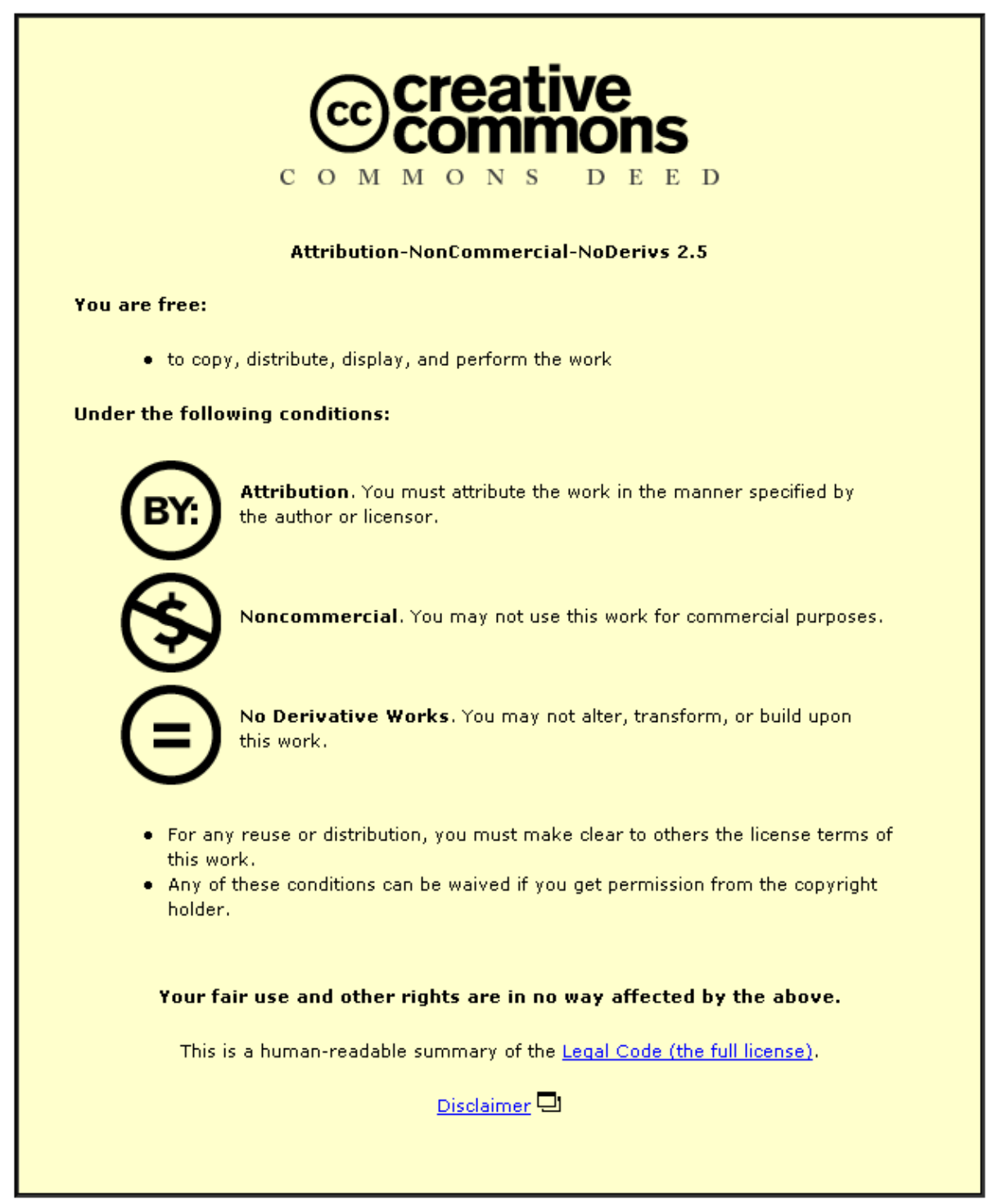

For the full text of this licence, please go to: http://creativecommons.org/licenses/by-nc-nd/2.5/ 
ISSN 1750-4171

\section{DEPARTMENT OF ECONOMICS}

\section{DISCUSSION PAPER SERIES}

Did the market signal impending problems at Northern Rock? An analysis of four financial instruments

Paul Hamalainen, Adrian Pop, Max Hall and Barry Howcroft

WP 2008 - 11 


\title{
Did the market signal impending problems at Northern Rock?
}

\section{An analysis of four financial instruments.}

\author{
Paul Hamalainen ${ }^{\mathrm{a}}$, Adrian Pop ${ }^{\mathrm{b}}$, Max Hall $^{\mathrm{c}}$ and Barry Howcroft ${ }^{\mathrm{c}}$
}

\begin{abstract}
The academic literature has regularly argued that market discipline can support regulatory authority discipline to monitor banking sector stability. This includes, amongst other things, using forward-looking market prices to identify those credit institutions that are most at risk of failure. The paper's key aim is to analyse whether market investors signalled potential problems at Northern Rock in advance of the bank announcing that it had negotiated emergency lending facilities at the Bank of England in September 2007. A further aim of the paper is to examine the signalling qualities of four financial market instruments so as to explore both the relative and individual qualities of each. Therefore, the paper's findings contribute to the market discipline literature on using market data to identify bank risk-taking and enhancing supervisory monitoring. In addition, the paper tests for evidence of an implicit "toobig-to-fail" policy in UK banking. Our analysis suggests that private market participants did signal impending financial problems at Northern Rock in advance of the bank announcing that it had negotiated emergency lending facilities. These findings lend some empirical support to proposals for the supervisory authorities to use market information more extensively to improve the identification of troubled banks.
\end{abstract}

Previous versions of this paper have been presented at a research seminar at Imperial College London, May 2008 and the IBEFA session on Northern Rock, WEAI $83^{\text {rd }}$ Annual Conference, $30^{\text {th }}$ June 2008. The authors would like to thank attendees for their constructive comments, which have been incorporated into this version.

Keywords: Banking regulation, bank failures, market discipline, early warning signals.

JEL Classification Codes: G14; G21; G28.

${ }^{\text {a }}$ University of Essex, Colchester, Essex, England, CO4 3SQ.

${ }^{\mathrm{b}}$ University of Nantes, 44322 Nantes Cedex 3, France.

${ }^{\mathrm{c}}$ Loughborough University, Loughborough, Leicestershire, England, LE11 3TU. 


\section{Introduction}

The academic literature has regularly argued that market discipline can support regulatory authority discipline to monitor banking sector stability [Evanoff and Wall, 2001a; and Flannery, 1998]. This includes, amongst other things, using forwardlooking market prices to identify those credit institutions that are most at risk of failure. An extensive literature has empirically analysed the risk sensitivity of subordinated debt (SND) yields and equity prices [Flannery and Sorescu, 1996; Flannery, 1998; Flannery and Nikolova, 2003; and Sironi, 2003] and to a lesser degree the competing ability of different instruments to identify problem banks [Gropp, Vesala and Vulpes, 2006; and Evanoff and Wall, 2001b]. In addition, some banking supervisory authorities are showing an increasing interest in the use and quality of market signals on bank condition to support more traditional monitoring mechanisms [European Central Bank, 2004 and 2005; Schmidt, 2004; Persson and Blåvarg, 2003; and Birchler and Facchinetti, 2007].

On September $14^{\text {th }} 2007$ the UK bank, Northern Rock, announced that it had negotiated access to emergency lending facilities at the Bank of England. This news precipitated the first run on a UK bank for 130 years. The run only subsided when the government announced on the evening of September $17^{\text {th }} 2007$ that all deposits would be guaranteed. This unique event of near bank failure provides an opportunity to investigate the risk-signalling qualities of investors in a modern financial market context. The paper's primary research aim is, therefore, to analyse whether market investors did signal potential problems at Northern Rock in advance of the bank announcing that it had negotiated emergency lending facilities. Financial innovation in the form of new market instruments, such as credit default swaps (CDS), and the 
rapid rise, in the past fifteen years, in UK credit institution SND issuance, facilitates an analysis of multiple financial instruments in identifying impending bank failure. In so doing, the paper also aims to explore the relative and individual signalling qualities of a number of market instruments and, therefore, further the debate on using market data in banking supervision.

The structure of the paper is as follows. Section 1 is a literature review on the two key facets associated with this research paper. First, there is a review on the use of market information in bank regulation and supervision with a particular focus on the debate as to whether it could enhance market and regulatory authority discipline. This discussion is supported by an analysis of the recent report released by the UK's Financial Services Authority into its own use of market information for supervisory purposes. Secondly, this section reviews the limited existing literature on the competing ability of different market instruments to identify problem banks.

Section 2 summarises the key events that culminated in the run on Northern Rock. The analysis provides a context for the subsequent sections of the paper that examine whether the market was able to signal impending difficulties at Northern Rock. Section 3 introduces the paper's research aims and questions and discusses the suitability of the Northern Rock case in examining the signalling qualities of market information. In addition, the contributions of this paper to the existing literature are emphasised. The section also explains the data and research methodologies utilised in the study. 
Section 4 presents the results on the signalling qualities of different market investors to the impending problems at Northern Rock. These are examined on an instrument by instrument basis. Section 5 concludes on the signalling qualities of each of the financial instruments. In addition, the implications for the use of market signals in banking supervision and the market discipline debate, more generally, are discussed.

\section{Section 1: Supervisory use of market information}

\section{Market discipline and market information}

The prices of financial instruments associated with credit institutions have two market discipline properties. First, they may increase an institution's funding costs and therefore induce direct market discipline. Secondly, market prices may signal to the supervisory authorities and other interested parties bank-specific (micro-prudential) or systemic bank fragility (macro-prudential) concerns. This use of market data is termed indirect market discipline and shall form the focus of this paper. For example, it has been suggested that the secondary market prices of uninsured bank liabilities may provide information that the supervisory authorities can use in setting up early warning systems for bank examinations, pricing deposit insurance or setting capital requirements [Berger, 1991]. Supervisory authority interest in the use of market information as a market discipline mechanism is becoming increasingly evident. For instance, bank regulators and supervisors in the US -- affiliated with the Federal Reserve System, Federal Deposit Insurance Corporation, and Office of the Comptroller of the Currency - have collected and used market information "informally" for supervisory purposes since the end of the nineties. According to Schmidt (2004), about $80 \%$ of the official documents (for example, risk assessments, 
supervisory plans and inspection reports) produced by these governmental and regulatory bodies contain explicit references to financial market information. The market indicators most often mentioned in supervisory reports are: debt ratings; stock prices; SND spreads; excepted default frequencies (EDFs) extracted from equity values; market capitalization; asset volatility; and analysts' opinions [also see Furlong and Williams, 2006]. The various indicators, published regularly in specific documents called Monthly Market Data Reports, serve to identify general trends in the banking industry, to detect "outliers," and to compare bank risk and performance across time and individual institutions. More recently, Sveriges Riksbank has begun to make more extensive use of market information to complement its conventional analysis of the soundness of the banking sector, which is mainly based on balance sheets and income statements. In its efforts to harness market monitoring, the Riksbank favours equity-based indicators, such as EDFs and Distance-to-Default (DD), because of the deeper liquidity in the stock market. The current use of market signals at the Riksbank is quite timid, but the experts in the Financial Stability Department anticipate promising developments in this direction in the near future [Persson and Blåvarg, 2003]. In the same vein, Birchler and Facchinetti (2007) discuss the suitability and pitfalls of market data for the assessment of banking and systemic risk from a Swiss perspective. Finally, the usefulness of market indicators for monitoring the banking system as a whole has been recognized by the European Central Bank (ECB) [European Central Bank, 2004; and 2005]. The ECB embraces a macro-prudential approach to financial stability and constructs aggregate measures of the DD that reflect the risk of the banking system as a whole. Although banking authorities in several countries are currently using market information to complement 
traditional supervisory tools, they seem somewhat reluctant to trigger specified corrective actions based on signals sent by financial markets.

The appeal of market-based information over accounting and supervisory information in the banking supervisory context is threefold. First, market data represents the aggregated opinions of a large number of market participants. Secondly, the data is forward-looking in contrast to the retrospective nature of accounting data. Finally, it has high frequency and is publicly available in a timely manner. On the other hand, market information may have qualities that are not consistent with supervisory authorities' requirements and therefore provide misleading indirect disciplining signals. Market prices reflect the private costs of default to the investor and not social costs and so market participants may be willing to accept higher risk-taking than the supervisory authorities. For example, the academic literature argues that equity holders prefer more volatile assets and focus on the upside compared to the supervisory authorities, whereas debt holders, who do not benefit from the upside, have incentives that are more aligned with the supervisory authorities. As Gropp, Vesala and Vulpes (2006) indicate, the relative importance of this moral hazard problem becomes more pronounced the closer the bank reaches insolvency. Therefore, prices based on debt financial instruments could be more informative to the supervisory authorities than equity prices. ${ }^{1}$ Other requirements for appropriate market signals are a deep and liquid market to inform efficient market prices, and standardised securities so that there is comparability across different credit institutions. Finally, market prices may contain factors other than credit risk, such as taxes and liquidity risk, which can cloud "signal-to-noise" qualities. 
A review of the empirical literature on market discipline and market signals highlights two generic types of study, each of which attempts to answer a specific research question:

1. 'Does market information accurately reflect contemporaneous information about a credit institution's condition?'

2. 'Does the market incorporate this information in a timely manner so as to add information to supervisory assessments?' And attached to this, 'Can market participants predict individual bank or system-wide fragility?'

Concerning the first question, Hamalainen (2007) conducts an extensive literature review of the existing market discipline studies on whether market prices (equities and SND) reflect the risks inherent in a credit institution (the accuracy debate). Generally, the findings are that equity prices/returns and SND yield spreads do reflect banks' risks as measured through balance-sheet or other market indicators [Flannery and Sorescu, 1996; Flannery and Nikolova, 2003; Sironi, 2003; and Hamalainen, Howcroft and Hall, 2007].

The second question, one of timeliness, is more pertinent to this paper. DeYoung et al. (2001) and Berger and Davies (1998) observe that bank examinations do provide new information that market prices do not immediately reflect. However, Berger, Davies and Flannery (2000) conclude that supervisory assessments are generally less predictive of future changes in performance than equity or bond market indicators, except when these assessments derive from a recent on-site inspection. In addition, Cole and Gunther (1998) found that the persistence of private information in bank examination ratings is exhausted within six months. Looking specifically at the 
predictive qualities of market instruments, Evanoff and Wall (2001b) find that SND spreads have some leading properties over capital adequacy measures in predicting bank condition. Jagtiani and Lemieux (2001) showed that, for their sample of five failed banks, spreads started rising as early as six quarters prior to failure. All-in-all, these findings concur with Flannery's (1998) summary that: "market assessments have at least a plausible chance of providing timely, accurate information that supplements the supervisory agencies' traditional ways of gathering and assessing bank quality."

A small literature has examined which market instruments may provide better predictive qualities of individual bank failure. As far as the authors are aware, only four studies exist. Three have compared the predictive qualities of SND yield spreads and equity-based market indicators, such as "distance to default", [Persson and Blåvarg, 2003; Krainer and Lopez, 2004; and Gropp, Vesala and Vulpes, 2006]. Two of the studies used a logit model methodology and one a descriptive approach. All of these studies appear to suggest that equity market indicators provide more value far from default, whereas yield spreads have a tendency to react close to default. The fourth study is by Swidler and Wilcox (2002). They compare Implied Volatilities (IVs) from exchange-traded options to share prices and sub-debt yield spreads for a small sample of US banks. Their findings suggest that there exist important comovements between the three market indicators. However, the IV estimates diverge at different times from the paths followed by stock prices and credit spreads. Evanoff and Wall (2001b) identify that, in establishing an early-warning system, the desire is to minimise the misclassification of problem banks as non-problem banks (type-I error). It is worth noting that small amounts of signal noise in SND yield-spreads may 
produce high frequencies of misclassification errors, especially if the objective of the supervisory authority is to detect the most risky banks. Given that the supervisory mission is to identify a relatively few "bad" banks amongst a large sample of mostly "good" banks, the classification problem regulators might face in practice is highly

relevant. ${ }^{3}$ Gropp, Vesala and Vulpes (2006) show that the different properties of bond and equity-based indicators help to reduce the risk of failing to discipline troubled institutions (type I errors). Equally, the findings of Swidler and Wilcox (2002) and the statistical analysis of the spread-risk relationship conducted by Bliss (2001) lend support to the idea of combining various risk indicators to improve the accuracy of bank distress forecasts.

\section{The FSA's use of market information}

Following the Northern Rock crisis, the head of the FSA's Senior Executive Management Committee commissioned its Internal Audit Division to review the FSA's supervision of Northern Rock prior to the events of August 2007 when the credit crunch commenced. The Internal Audit Division's report was published in April 2008 [FSA, 2008]. The report identifies key supervisory failings in the case of Northern Rock and weaknesses more generally in the supervision of a sample of other large credit institutions. The report provides recommendations for firms' supervision in the future. One area that the report examines, and which is of particular interest in the context of this paper, is the use of market information by the supervisory authorities. This section of the paper reviews the report's findings on the FSA's use of market information in banking supervision and contextualises the findings in advance of presenting the research aims of this paper. 
The Internal Audit Division's report examined the Use of Intelligence by a sample of banking supervisory teams, one of which was the team responsible for Northern Rock. This covered both external and internal sources of information. The same section of the report also assesses the flow of this information between different parts of the FSA, which can, therefore, facilitate peer analysis by supervisory teams. The report found that "there were significant weaknesses in the effective flow of information between, and use of intelligence by, different parts of the FSA." For example, at a number of hierarchical levels within the organisation (including individual supervisory team and sector team), the report concluded that: "none of the teams reviewed understood its role to include identifying outlier firms from peer analysis of business models." The report clearly states the implications of this: "The resulting situation, where no team or individual within the FSA had the objective or resource to identify outlier firms based on financial analysis or any non-ARROW generated metric, meant there was a gap in the intelligence available to supervisors." This is not to say that the teams did not receive any information that would enable them to conduct such analyses. ${ }^{4}$ The banking sector team and relevant individual supervisory teams did receive "simple analysis and collation of banks" results and share price movements." However, the report goes on to state that: "the work does not appear to have been well used by supervisors and appears to have been considered a low priority as the resource was reduced in February 2007." Beyond simple share price movement analysis the only other external market data that appears to have been used were credit ratings and analysts' reports. Again, in relation to this market data, the report identifies that: "there was confusion about responsibilities ... for obtaining and analysing external information" and that: "there was no clear mechanism for ensuring that a supervisor received all relevant credit ratings and analysts' reports for their 
firms." Two of the desired outcomes from the Internal Audit Division's examination of the Use of Intelligence were: "External analysis should be considered by supervisors in order to enhance their knowledge of the firms in relation to market sentiment", and, "Responsibility for conducting on-going peer/outlier analysis is clearly assigned". Beyond the report's own conclusion that market data provides considerable opportunities to enhance supervisory analysis, there is also the question as to whether the supervisory authorities should be widening their information scope to incorporate simple market data from other financial instruments, such as subordinated debt and credit default swaps and, where possible, performing more complicated analyses on existing data sources. This paper will provide some such analysis in the Northern Rock context and offer some suggestions for the supervisory use of market data.

\section{Section 2 - Northern Rock: The events leading up to the run on the bank's deposits}

This section provides an analytical background to the events that culminated in the announcement on Friday September $14^{\text {th }} 2007$ that Northern Rock has been granted emergency funding facilities from the Bank of England. The analysis provides a context for the subsequent sections of the paper which examine whether the market was able to signal impending difficulties at Northern Rock. For reference purposes, appendix one tables the events both before and after September $14^{\text {th }}$ in detail. This section utilises data from the London Stock Exchange Regulatory News Service and other financial media to identify key dates and access source material. 
Northern Rock opened 2007 reporting record profitability in the last financial year [Northern Rock, 2007a]. The markets reacted to the news with the company's share price rising $64 p$ on the day to close at $1212 p$. This was $12 p$ off the record high for the shares achieved only 3 weeks earlier. As a result of these record figures, the company increased its strategic target for return on equity to $20 \%-25 \%$ for 2007 . The strong performance continued into 2007 with Northern Rock reporting a positive quarterly trading statement on $2^{\text {nd }}$ April 2007. Northern Rock was on course for an $18 \%$ increase in full-year profits and this was driven by sustained lending growth and generally benign economic conditions. For example, net lending in the first quarter was up 34\% on the same period last year. The Chief Executive reflected the positive position and outlook stating: "We have started 2007 strongly, with lending performance well ahead of the comparable period last year and a strong pipeline of business set to deliver asset growth in the top half of our strategic range" [Northern Rock, 2007b]. The bank's trading statement had identified that due to an unexpected Bank Base Rate rise in January the resultant Base Rate-Libor gap remained noticeably higher than in 2006, but the bank did not believe that its profit growth forecast required adjustment. ${ }^{6}$ Figure 1 illustrates the growing divergence in the relationship between 3-month Sterling Libor and the Bank of England Base Rate since the beginning of 2006. Northern Rock's reliance on securitisation to fund its rapid growth strategy, and how this contrasted with the other two mortgage banks' strategies was not lost on the market. As Hughes (2007) states: “Northern Rock's Adam Applegarth has embraced securitisation as a way of funding aggressive growth. Steve Crawshaw has dismantled Bradford \& Bingley. ... Alliance \& Leicester has proved a low-risk investment generating good returns. But Mr. Pym's strategy could surely have been executed with greater drive. Alliance \& Leicester has taken an overly cautious view of 
the mortgage market, pulling back amid fears of a housing crash at a time when rivals have dashed headlong in pursuit of growth. This relative caution helps explain why Alliance \& Leicester has not needed to go down the securitisation route pursued by Northern Rock. If you don't grow, you don't need more capital."

Insert figure 1 here

The $27^{\text {th }}$ June 2007 proved a turning point for Northern Rock's growth. The bank issued a Pre-close period statement to the London Stock Exchange. This clearly stated that it expected full-year profits to fall short of analysts' forecasts and was subsequently viewed by the market as a profits warning. The reasoning for the profit realignment is neatly encapsulated in the Pre-close statement: "Expectations for higher interest rates in the UK have risen further than anticipated at the time of Northern Rocks' first quarter Trading Statement on $2^{\text {nd }}$ April 2007. Given Northern Rock's Libor-dominated funding platform, we have a structural mismatch between Libor and Bank Base Rates and because of changes in the forward interest rate curve. ... In times of rising rates this dampens revenue growth with the opposite occurring as rates fall” [Northern Rock, 2007c]. The profits warning release on $27^{\text {th }}$ June 2007 appeared to act as the impetus for the market, more widely, to identify and report the weaknesses in Northern Rock's business model. In particular, the bank's significant reliance on wholesale funding to support its rapid growth and the mismatch between its funding source, based on Libor rates, and its revenue source, based on Bank of England Base Rates. These factors became the focus in subsequent reporting on Northern Rock's performance [Croft and Tett, 2007; and Hill, 2007a]. An analyst quoted in Croft and Tett (2007) neatly encapsulates Northern Rock's business model: 
"Northern Rock is supposed to be a safe, conservative mortgage bank. If investors wanted to take a leveraged bet on interest rates they'd have gone elsewhere".

On $25^{\text {th }}$ July 2007 Northern Rock released its Interim results for the six months to $30^{\text {th }}$ June 2007 [Northern Rock, 2007d]. The Chief Executive reiterates that profits will be impacted by interest rate movements: "The outlook for the full year is being impacted by sharp increases in money market and swap rates seen in the first half. This has resulted in a negative impact on net interest income as mortgage pricing in the market generally has lagged behind increases in funding costs in the year to date." Separately, the bank announces that: "The introduction of Basel II, which requires less capital to support new lending, also enables a review of the company's dividend policy. The interim dividend therefore increases by $30.3 \%$ to $14.2 \mathrm{p}$, payable on $26^{\text {th }}$ October 2007."

Investors' concerns over Northern Rock intensify as a result of the US sub-prime turmoil coming to the fore in late July and early August 2007. Sharp falls in global stock markets and the seizure of credit markets led the US Federal Reserve and the ECB to pump unprecedented amounts of liquidity into the financial system from $9^{\text {th }}$ August onwards. The sharp rise in Libor rates in early August (see figure 1) raised concerns that higher funding costs would squeeze Northern Rock's margins and limit growth [Thal Larsen, 2007a] and force the bank to make a further profit warning [Hill, 2007b]. On top of this, the closure of credit markets prevented Northern Rock from distributing securitised assets and thus tapping its all-important wholesale funding sources [Thal Larsen, 2007b]. As one fund manager quoted in Thal Larsen (2007a) states: "If the asset-backed securities market is shut off, then the Northern 
Rock business model is in serious doubt. It depends how long people hold this view". Concerns over both Northern Rock's access to funding and at what cost continued in the market [Hume, 2007] until the Tripartite announcement on the morning of Friday $14^{\text {th }}$ September 2007 that the Bank of England is providing Northern Rock with access to emergency funding at a penal rate of interest. At the same time, Northern Rock issued a Stock Exchange statement and this emphasised the impact of the funding mismatch between Sterling Libor and Bank Base Rates on its future profitability [Northern Rock, 2007e]. The statement reads: "It has now become clear that the global credit and liquidity markets have not recovered in the early part of September, and that there continues to be a severe liquidity squeeze. In the UK, this is demonstrated by 3 Month Sterling Libor currently running at over $1 \%$ higher than Bank Base Rate. In these circumstances, Northern Rock has to take action to preserve liquidity and to maintain margins on its current loan book, while modifying its lending approach to avoid writing new business that is unprofitable in current conditions." This news initiated a run on the bank's deposits, which only subsided when HM Treasury announced on Monday $17^{\text {th }}$ September 2007 an explicit full guarantee of Northern Rock's existing deposits.

Following the announcement on Friday $14^{\text {th }}$ September, the Northern Rock franchise was in tatters. The bank swiftly amassed large borrowings with the Bank of England as retail and wholesale sources of funding withdrew from the bank [Northern Rock, 2008] and the securitised markets remained closed. By the end of 2007, Northern Rock had borrowed $£ 27$ billion in emergency lending from the Bank of England to replace $£ 28$ billion in retail and wholesale funding that had deserted the bank. At the same time, three potential private bidders were interested in buying the bank. Given 
the scale of Northern Rock's borrowings with the central bank, the Government was deeply involved in the negotiations with the aim of securing the return of taxpayers' money as swiftly as possible. Ultimately, on $17^{\text {th }}$ February 2008 the Government decided that the best course of action was to temporarily nationalise Northern Rock.

\section{Section 3: Research aims and methodology}

\section{Research aims and questions}

Given the preceding literature review on the potential supervisory benefits of using market information as a predictor of bank risk and the discussion on the use of market information by the FSA, the paper's research aims and questions are:

\section{Aims}

- To examine whether market investors signalled potential problems at Northern Rock.

- To examine the signalling qualities of different financial instruments.

\section{Questions}

- Did market investors signal increased risk at Northern Rock in advance of requiring emergency assistance from the Bank of England?

- What can we learn from the Northern Rock experience concerning the use of market signals in banking supervision?

A study of the Northern Rock context is particularly pertinent in addressing these questions and furthers the literature on market signalling in a number of ways. First, existing studies in this area have applied a proxy for bank failure (such as a 
downgrade in the deposit-taking institution's credit rating [Gropp, Vesala and Vulpes, 2006] or downgrade in supervisory rating [Krainer and Lopez, 2004]). In contrast, Northern Rock represents a clear case of near individual bank failure. Secondly, existing studies have covered substantial sample time periods where there was more than one instance of "bank failure". As a consequence, their analyses are partly clouded by the "failure" of a number of institutions in their sample. Thirdly, financial innovation in the form of new market instruments, such as CDSs, and the rapid rise in UK credit institution SND issuance in the past fifteen years [Hamalainen, Howcroft, and Hall, 2008], and consequential deepening of the market, provide an opportunity to explore and compare the market signalling qualities of a number of financial instruments in a modern financial market context. Existing studies have tended to focus on equities and SND, and in the case of SND usually used data from the early 1990s when the debt markets (in particular in Europe) were substantially less developed. Fourthly, this paper introduces a further potential metric in signalling individual bank risk-taking through extracting implied idiosyncratic volatility from bank's traded option contract prices. Finally, the single country study of this paper limits the wider relevance of the research findings and conclusions, but provides a cleaner analytical context in which to examine the research questions. For example, the study by Gropp, Vesala and Vulpes (2006) covers numerous European countries and as a result has to accommodate the influence of different government responses to bank fragility. The UK context of this research paper is particularly pertinent in this case, because there has been an implicit belief that UK banks, contrary to continental European ones, do not benefit from "too-big-to-fail" (TBTF) type conjectural guarantees [Sironi, 2003]. ${ }^{8}$ Last but not least, almost all papers in this area use data from "benign" or tranquil sample periods to discriminate between "bad" and "good" 
banks. One of the main contributions of our paper is studying the informational content of bank security prices in a stressful macroeconomic environment that is likely to affect the financial conditions of the whole banking/financial system.

\section{Data and research methodology}

In answering the research questions, the paper analyses the market signals for Northern Rock compared to a set of eight peer UK banks. ${ }^{9}$ The selected banks, including Northern Rock, are the nine largest in the UK and represent over $80 \%$ of the UK banking system in asset terms. In addition, each of these banks has market trading in the alternative financial instruments under investigation. Therefore, the data comprises CDS spreads, SND spreads, implied volatilities from options prices and equity measures of bank risk (prices, trading volumes, returns and DD) for all of the sample banks from the beginning of 2006 or 2007 to the announcement of access to emergency liquidity facilities on Friday $14^{\text {th }}$ September 2007. The CDS data is sourced from Credit Market Analysis, the options prices from Reuters and Datastream Thomson Financial and the equity and SND data from Datastream Thomson Financial.

The most appropriate manner in which to answer the research question "Did market investors signal increased risk at Northern Rock in advance of requiring emergency assistance from the Bank of England?" is to apply a standard "early-warning" model to the data sets in the same vein as Gropp, Vesala and Vulpes (2006). However, the small sample of relevant UK banks prevents the application of such a methodology. Therefore, the research question is tackled in a graphical and descriptive statistical manner similar to Persson and Blåvarg (2003). Graphical representations of the 
different market signals are presented to identify trends, with key market dates mapped onto the graphs to support the analysis. Wherever appropriate, different analytical techniques are applied to examine alternative market indicators. Adopting descriptive statistics prevents statistical significance testing of market instruments' predictive capabilities. However, in light of the study's unique context and the clear under-utilisation of market information by the FSA, the study still contributes to the two posited research questions. In addition to analysing the signalling qualities of a number of market instruments in advance of the announcement date, the paper also examines equity investor responses as a result of the announcement on September $14^{\text {th }}$ 2007. An event study methodology is applied and by creating control groups the test analyses equity holder perceptions of the TBTF policy.

The study's second research question is answered by analysing the paper's empirical findings for each financial instrument for the first research question and comparing and contrasting the outcomes.

\section{Section 4: Empirical findings}

This section presents the findings of the research and is structured by market instrument type. The final part of the section brings together the key themes to compare the signalling qualities of each financial instrument and their potential application for supervisory authorities. 


\section{Equities}

Each of the banks in the study is listed in the FTSE100 and therefore has a liquid market for its equity liabilities. The existing literature presents a number of different equity indicators based on stock prices, trading volume, returns and option-pricing theory; all are examined in turn here.

\section{Equity prices}

The appeal of using equity prices as a signalling mechanism is that the data is readily available, although there is no unambiguous link between equity prices and default risk, because share price movements are also driven by other factors [Persson and Blåvarg, 2003]. In the Northern Rock context, however, their share price had been consistently falling since its record high in February 2007 and was identified in The House of Commons Treasury Committee (2008) report as one potential warning sign of impending problems. The deterioration in Northern Rock's share price becomes truly apparent after the profit warning issued in late June 2007 and when their equity price data is compared with peer banks. Figure 2 presents the share price data for the three UK mortgage banks; the arrow indicates when Northern Rock issued a profits warning.

Insert figure 2 here

The deterioration in Northern Rock's share price is all the more startling when UK banks' share prices are rebased back to January 2006 (figures 3 and 4). Figure 4 emphasises that Northern Rock was the best-performing UK bank share during 2006. Nevertheless, the graphs again suggest that the equity market became particularly 
concerned with Northern Rock after the profit warning in June with accelerating deterioration in its share price. This may well be because the profit warning Stock Exchange Statement highlighted, for the first time, the fundamental shortcomings of Northern Rock's business model to a wider audience.

Insert figures 3 and 4 here

\section{Equity trading volumes}

Like share prices, equity trading volumes have no direct link with default risk. At best, analysis of trading volume data can simply indicate to the supervisory authorities that potential issues may have been identified by equity market participants that require further investigation. In the Northern Rock case, simple peer analysis with other mortgage banks illustrates consistently higher trading volumes in Northern Rock shares after the profits warning in June (see figure 5). The higher volumes may simply represent investors searching for potential value stocks, but the jump to average trading volumes above 10,000 does warrant further investigation. The high spike in trading in early August suggests that the market had by then understood the implications of the seizure in wholesale credit markets on Northern Rock's business model. In a similar vein, the rise in Bradford \& Bingley's trading volumes from June 2007 may have alerted the supervisory authorities to potential issues that again merited further investigation. Please note, the authors did not compare the trading volumes with the larger non-mortgage banks because their trading volumes are considerably higher.

Insert figure 5 here 


\section{Equity returns}

A further approach is to analyse whether equity returns rather than price levels contain any signals about bank condition. For each mortgage bank we created a valueweighted portfolio of all of the other eight banks. We computed weekly returns for the mortgage bank and each of their respective portfolios of banks and calculated the cumulative weekly return difference between January 2006 and $13^{\text {th }}$ September 2007. Figure 6 presents the results. Like for the equity price signal graphs, it is only after the profit warning in June that Northern Rock's equity returns become significant and thus signal a potential concern.

Insert figure 6 here

\section{Distance to default}

A further approach in extracting information from equities is based on option-pricing theory, which treats the equity as a call option on the company. This enables investors' implicit views of default risk to be determined in the form of the Distanceto-Default (DD) measure. This measure calculates the number of standard deviations a banking firm is away from its default point (i.e. the asset value at which the firm will default or have zero market net worth). We derive our calculations of DD in a similar fashion to Gropp, Vesala and Vulpes (2006) and Persson and Blåvarg (2003). First, we estimate the asset value and asset volatility for each bank from the market value and volatility of equity and the book value of liabilities by solving numerically (using the Newton-Raphson method) a non-linear system of two equations: (1) the 
value of equity modeled as a call on the bank assets using a standard options pricing based framework à la Merton (1974) and Black and Scholes (1973); and (2) the instantaneous relationship between assets and equity volatility derived from Ito's lemma. Then, we compute DD using the KMV framework described in Crosbie and Bohn (2003). The final step in our derivation of a sophisticated equity-based indicator would be to convert the DD for each bank in our sample to a probability of default or a term structure of default probabilities. Moody's KMV uses a rich database on historical defaults and bankruptcy rates to derive the empirical distribution mapping the DD to a corresponding expected default frequency for different time horizons. Alternatively, as we do not have access to a historical default database, we scaled the DD to a probability using Merton's (1974) model. However, the results were deceptive, i.e. the default probabilities were largely undervalued, essentially zero for all banks, except Northern Rock after August 2007. This is because the empirical distribution of default rates exhibits wider tails than the normal distribution under the original Merton model.

Our DD results are presented in figure 7. In line with our previous equity findings, equity investors' perceptions of risk at Northern Rock deteriorated very rapidly after the profit warning in June compared to the sample banks. From then on, although all sample banks were reporting declining DD indicators (greater likelihood of default), Northern Rock was perceived as the most likely to default, as were the smaller mortgage banks.

Insert figure 7 here 
Summarising the equity analysis, investors were signalling potential concerns as early as February 2007 as Northern Rock's share price was gradually falling from its historical highs in that month. However, it is only after the profit warning in June 2007 that all of the equity market signals began to clearly indicate that investors had some concern with Northern Rock compared to peer banks. From then on, the share price, equity returns and likelihood of default were on a distinctly downward path compared to other mortgage and non-mortgage banks, and share trading volumes were significantly above the long run average.

\section{Time-varying estimates of Implied Idiosyncratic Volatilities from bank's exchange-traded option contracts}

Among the various market-based indicators, the volatility of stock returns is a strong candidate to flag significant increases in the probability of a bank facing financial distress. Instead of using historical volatility (HV) measures of bank share prices as a basis for supervisory action, a better idea would be to focus on implied volatilities (IVs) from exchange-traded options to bank share prices. The appeal of considering implied rather than historical volatility estimates is threefold. First, in contrast to HV, which is by its very nature a back-ward looking measures of the bank's equity risk, IV is inherently a forward-looking, market-based, forecast of the future volatility of the underlying asset. This important difference implies that IVs may contain reliable information about stress events not captured in time series of past returns. Second, recent findings from the option literature indicate that IV levels contain virtually all relevant information about future realized volatility [see Mayhew, 1995; Christensen and Prabhala, 1998; Mayhew and Stivers, 2003; and Diavatopoulos, Doran and Peterson, 2008]. In addition, according to Dennis, Mayhew and Stivers (2006), the 
daily changes in IV contain useful incremental information about future return volatility, beyond the previous IV level. ${ }^{10}$ In the banking context, Swidler and Wilcox (2002) show that IV estimates have lower error forecasts of future volatility than HVs do and significantly improve forecasts based only on HVs. Third, at least for the largest banking organizations, the market for option contracts on bank equity is active, deep, and sufficiently liquid to provide reliable signals to supervisors. Among the UK listed banks, all banks included in our stock market sample (except Bradford \& Bingley) have option contracts that are traded on London International Financial Futures and Options Exchange (LIFFE).

For the purpose of our analysis, we extracted detailed information on bank equity options contracts (option type, lot size, market price, ${ }^{11}$ volume of trading, strike price, exercise price, expiry date, trading cycle etc.) from Reuters and Datastream Thomson Financial. Table 1 summarizes basic descriptive statistics on key variables characterizing the option contracts on UK listed banks' stocks traded on LIFFE in 2007 and highlights that the option market is deeper and more liquid for the largest UK banks. However, the option contracts on the two mortgage lenders' equity were also actively traded during the analyzed period and option open interest is reasonably high. This is quite important as IV estimates tend to be noisy for thinly traded option contracts [Mayhew and Stivers, 2003; and Dennis, Mayhew and Stivers, 2006]. Not surprisingly, the highest Put/Call open interest ratios are observed for Northern Rock (7.28:1 on average), indicating that investors were starting to conjecture that the stock market will go down and selecting financial instruments that gain value when prices decline rather than when they rise. 
Insert Table 1 about here

As each bank in our sample has a whole specter of traded options with different strike prices and maturities, we construct a "standardized" measure of IV using a methodology that is similar to Mayhew (1995) and Swidler and Wilcox (2002). Our IV estimates are based on the nearest two "at-the-money" options (i.e. the most liquid series) - one above and one below the underlying price - using values from the nearest expiry month options. Since strike prices are set at standard intervals for each class, options are rarely at the money. Consequently, we interpolate between the two IVs to calculate an estimate of the IV for a hypothetically "at-the-money" Call/Put option. We next average the IVs of the two (Call and Put) option contracts to obtain the IV for options with the strike price nearest to the underlying bank stock price. The last stage includes an interpolation of maturities in order to obtain IV estimates for a hypothetical at-the-money option having a 30 day constant maturity. ${ }^{12}$ As all option contracts on UK listed banks' stocks traded on LIFFE are American-type options, the IVs are computed using the Cox-Ross-Rubinstein binomial tree model to take into account dividends and the possibility of early exercise [Cox, Ross, and Rubinstein, 1979].

From a bank supervisor's perspective, it is useful to distinguish between fluctuations in IV time-varying estimates due to changes in bank risk profile and fluctuations induced by the changes in the volatility of the market. To decompose the total implied volatility into systematic and idiosyncratic components, we first need to construct a barometer of market volatility. The equity volatility index for the UK was computed in the same manner as individual banks' IVs, i.e. by taking implied volatilities from 
Calls and Puts traded on the FTSE100 index that are near the money. Following previous studies on implied volatility dynamics [Dennis, Mayhew and Stivers, 2006; and Diavatopoulos, Doran and Peterson, 2008], we use two methods to estimate the individual bank stock's implied idiosyncratic volatility (IIV). ${ }^{13}$ The first method is based on the variance decomposition implied by the market model, while the second method uses a decomposition of the total implied variance based on the discrete-time version of the Ornstein-Uhlenbeck stochastic process (see Appendix 2 for technical details). In our subsequent analysis, we favor the second method for two distinct reasons: (i) it takes into account the mean-reversion behavior of market IV, which is an essential time series property of implied volatility indices; (ii) it generates a smaller number of bank-days where the IIV estimate is negative. ${ }^{14}$ As a result, we only report IIVs using the second method.

Table 2 describes the statistical distribution of our two measures of volatility implied by the market prices of the options contracts on UK listed banks' stocks (IV and IIV) after release of the profit warning by Northern Rock and before the BoE decided to grant financial support on September $14^{\text {th }}$. Not surprisingly, the highest values for both measures of IV are observed for the two mortgage lenders, Alliance \& Leicester and Northern Rock. By contrast, HSBC and Lloyds, two large international banks, have the lowest risk profile according to our IV metrics. It is worth noting that the implied idiosyncratic variance represents a substantial portion (almost 70\%, on average) of the total implied variance. This is an important result because, from a micro-prudential perspective, bank supervisors should be more concerned about changes in bank specific risks rather than changes in volatility of the whole market. 
Insert Table 2 about here

To visualize the way in which the option market reacted to the deterioration of bank financial conditions prior to the Northern Rock crisis, we plot in Figure 8 the time evolution of our IIV indicator for our sample of banks between January $1^{\text {st }}$ and December $31^{\text {st }}, 2007$. As is the case with the equity indicators described in the previous section, the two mortgage lenders included in our option sample were perceived as more risky compared to the larger UK banks. Equally, the option market flagged bank-specific signs of vulnerability only after Northern Rock issued its profits warning in June 2007. Despite the financial support granted by the Bank of England on September $14^{\text {th }}$, concerns about Northern Rock's insolvency persisted in the option market after that date.

Insert figure 8 here

\section{Subordinated debt}

The most commonly used measure of risk where bond markets are concerned is bond spread; that is the excess yield on a bank's bond over and above the yield on a government bond of the same maturity. The market discipline literature has frequently espoused the potential benefits to the regulatory authorities of SND. In contrast to other debt holders (Certificates of Deposit and senior debt holders) the incentive of subordinated debt-holders to monitor and limit bank risk-taking is more aligned with the supervisory authorities (and hence taxpayers). This implies that they would exert a greater restraint on bank management and, as such, is a suitable instrument of market discipline [Hamalainen, Hall and Howcroft, 2003]. These benefits have led to proponents of SND suggesting that large deposit-taking institutions frequently issue 
sizeable amounts of subordinated debt; in other words, a mandatory subordinated debt policy [US Shadow Financial Regulatory Committee, 2000]. Therefore, it is most appropriate, in line with other studies, that subordinated debt spreads are analysed.

UK banks have been issuing SND in record levels since 1999 and, in value terms, are the second largest issuers of publicly-issued debt after the US [Hamalainen, Howcroft and Hall, 2008]. Subsequently the market has become extremely liquid and therefore offers risk-signalling potential. In this study, we focus on sterling-issued SND only because this is the currency in which mortgage banks primarily issue and because existing market discipline studies have shown that currency of denomination does influence SND spreads [Hamalainen, Howcroft and Hall, 2007]. In addition, we only select SND that indicates regular trading activity and which are neither perpetual in maturity nor callable.

Figures 9 and 10 present the findings for the mortgage banks. The data has been split based on the number of years remaining to maturity. Figure 9 presents those bonds with ten years and less to maturity and clearly shows that Northern Rock spreads had been declining until the profit warning in June. Subsequently, the spreads begin to rise, but it is only with the start of the credit crisis in early August that Northern Rock's spreads widen significantly to potentially signal any concerns (see ellipsoid). By then the regulatory authorities were well aware of the potential funding difficulties that Northern Rock may experience and they were in regular contact with Northern Rock. Figure 10 presents longer maturity SND and emphasises that it is only with the onset of the credit crisis that Northern Rock SND spreads may have begun to signal divergences from fellow mortgage banks, although Bradford \& Bingley's spreads 
were also widening at this time (see ellipsoid). Prior to that, all longer dated mortgage bank SND were tracking a very similar path.

Insert figures 9 and 10 here

For comparative purposes, figures 11 and 12 report the SND spreads for a selection of larger UK banks with less than 10 years to maturity and greater than 10 years to maturity respectively. In both maturity groups, prior to the turbulence in credit markets the spreads were generally lower than those of the equivalent maturity mortgage banks. However, the onset of the credit crisis, in general, brought mortgage banks and non-mortgage banks SND spreads closer together. Therefore, it is difficult to deduce any bank-specific risk signals. Noticeably, however, throughout the sample period the larger banks' spreads track a very similar path with no discernable bankspecific shifts away from peer banks. This is in contrast to those witnessed in the Northern Rock case.

Insert figures 11 and 12 here

Summarising the SND spread data trends, investors were recognising increased risk in all banks from July 2007 onwards, suggesting market-wide, rather than bank-specific influences. Extracting reliable signals that there was impending bank failure at Northern Rock was not possible. In fact, in the early part of 2007 shorter-dated Northern Rock spreads were tightening. There were discernable rises in Northern Rock spreads following the seizure of credit markets in early August and further marked rises in spreads in early September. However, Bradford \& Bingley were also 
reporting widening spreads at this time and that was partially clouding any mortgage bank specific risk signals. In addition, figures 11 and 12 illustrate that larger bank SND spreads were also widening thus creating further noise; although, in contrast to Northern Rock no larger bank saw its spreads shift significantly away from peer banks.

\section{Credit Default Swaps}

Credit default swap growth in the past ten years provides an opportunity to explore the risk signalling qualities of this financial instrument. The characteristics of this credit derivative are such that it should provide a clear measure of default risk in the underlying company's debt, the spread reflecting the measure of default risk. CDS prices are available for Senior and SND debt, however, in this study, the authors have used senior debt spreads only. This is far from ideal, but one of Northern Rock's peer mortgage banks, Bradford \& Bingley, does not have tradable credit default swaps based on SND. The SND analysis above showed that Bradford \& Bingley's SND spreads widened in late August and, therefore, for comparative purposes the authors felt that it is important to include this peer bank.

Figure 13 presents the results for mortgage banks on one-year maturity CDS contracts. On an absolute basis, both Northern Rock and Bradford \& Bingley are viewed as more risky than Alliance \& Leicester. This is all the more apparent in figure 14, which includes all of the non-mortgage banks as well. Then only Standard Chartered has spreads that are comparable with Northern Rock and Bradford \& Bingley. In the summer of 2007 the market for mortgage bank CDSs dries up, until in mid-August when Northern Rock registers significant widening spreads. This is 
undoubtedly reflecting the funding fears in the wholesale markets at the time.

Notably, the same concerns are not applied to Bradford \& Bingley and Alliance \& Leicester. This in turn suggests that investors were specifically becoming concerned with Northern Rock's creditworthiness. Analysing the same data on a relative basis, however, clouds the picture. All of the non-mortgage banks' spreads were widening significantly in late July, albeit from very small bases, and, therefore, the considerable relative rise in Northern Rock's spreads in August was being matched by equally spectacular relative rises in the larger UK banks. In this case it would be hard to argue that bank-specific risk factors are being signalled by the CDS market. In addition, the spectacular rises in HSBC and Royal Bank of Scotland's one-year risk protection cloud the signals somewhat further.

Insert figures 13 and 14 here

Figures 15 and 16 present the findings for senior tier, five-year maturity CDS contracts since January 2007. This confirms the points made in the one-year CDS discussion above, except that, in absolute terms, Standard Chartered is now viewed by the market as containing more default risk than Northern Rock and Bradford \& Bingley.

Insert figures 15 and 16 here 


\section{Comparative signalling analysis of the three financial instruments and their application by the supervisory authorities}

Of the four financial instruments analysed in this study, equities appear to present the earliest and clearest signs of potential concerns with Northern Rock prior to the announcement in September 2007. There were bank-specific falls in prices and returns, trading volume registered a markedly upward shift, and the DD indicator rapidly deteriorated (a sign of increased bank default risk). However, the bankspecific signs only became apparent after Northern Rock issued a profit warning in late June. It is at this stage that the bank explained how funding mismatches would prevent analysts' profit forecasts from being met. This disclosure appears to have highlighted to the market the weakness in Northern Rock's business model and, therefore, subsequent divergence in the Libor-Bank Base Rate relationship cemented further falls in Northern Rock's share price.

The second metric of bank financial distress analyzed in the present study is the idiosyncratic component of IV from bank's exchange-traded option contracts. This forward-looking market indicator has been neglected so far in the market discipline literature (a notable exception is however Swidler and Wilcox, 2002). As is the case with equity indicators, the mortgage lenders appear to be more risky compared to the other UK banks a couple of months before the Bank of England decided to take action, i.e. only after Northern Rock released its profit warning.

SND spreads and CDS spreads were considerably slower in indicating concerns with Northern Rock. With hindsight, both instruments reported significant jumps in Northern Rock's spreads following the shut down in wholesale credit markets. In that 
way these markets did react prior to the bank requesting funding assistance from the Bank of England. However, these signals were extremely late and also very difficult to decipher for bank-specific risk elements.

In the case of SND spreads, it was difficult to extract clean bank-specific signals from the general market trend for rising bond spreads at the time. For example, finding bonds of comparable maturity issued by more than one mortgage bank was not possible and so term structure components were also reflected in spread comparisons. Therefore, although the UK bank-issued SND market has become considerably larger and more liquid in the past ten years, finding comparable SND instruments is difficult for risk signalling purposes. This is why proponents of SND market discipline propose mandatory subordinated debt policies that contain standardised debt structures.

In the case of CDS spreads, the findings illustrate that the CDS market is still not sufficiently deep to extract clean signals. There was no trading in mortgage banks' CDS for some time during the summer, despite volatility in the credit markets. Therefore, liquidity risk is currently an issue for CDS spread signals. In addition, it is difficult to decipher bank-specific risk signalling depending on whether one examines absolute spread levels or relative spreads. In absolute terms, Northern Rock was consistently perceived by the CDS market as one of the riskier UK banks. Therefore, the market did identify Northern Rock's risk characteristics. However, Bradford \& Bingley and Standard Chartered Bank were also exhibiting comparably high absolute spreads. The onset of the liquidity crunch in August led the larger UK banks' CDS spreads to rise dramatically and therefore their relative spreads rose considerably 
compared to Northern Rock. In that context, does Northern Rock, or the larger banks, merit attention from the supervisory authorities? A further difficulty in identifying bank-specific risk in CDS spreads is the number of different maturities available and potentially conflicting information. For example, one-year maturity CDS spreads for Alliance \& Leicester were predominantly below those of Northern Rock and Bradford \& Bingley during 2007 (see figure 13). However, for five-year maturity CDS spreads this was not the case (see figure 15).

Apart from comparing the signalling quality of the three financial instruments, the study's findings contribute to the academic debate on the timeliness of market information compared to supervisory authority actions. The House of Commons Treasury Committee (2008) reports that the supervisory authorities became concerned with Northern Rock when the wholesale credit markets seized up on $9^{\text {th }}$ August 2007. This prompted the regulatory authorities to initiate regular communication with Northern Rock and begin considering a number of solutions, including selling the bank to a larger UK credit institution. Mapping this information onto the market signalling results illustrates that the equity market did provide some evidence of investor concern in advance of the regulatory authorities contacting Northern Rock. In contrast, the SND and CDS markets did not. Both of these markets appear to have structural limitations which hamper their signalling capabilities. Therefore, this paper suggests that the regulatory authorities could make more use of market information to enhance their monitoring of bank risk, but at this time efforts should be concentrated on equity market signals. Furthermore, the results indicate that the FSA could adopt far more rigorous and sophisticated equity analysis than is currently prepared in order to monitor market sentiment. There were a number of relatively straightforward 
equity indicators that should have alerted the supervisory authorities to, at least, undertake further investigation into Northern Rock's increasingly negative market perception. This is not to suggest that earlier intervention by the supervisory authorities could have prevented Northern Rock from experiencing what was a rapid deterioration in liquidity. The profit warning (which prompted the first clean market signs of concern) was not released until late in June 2007 and the unprecedented collapse in wholesale credit markets started in early August 2007. Within a month, Northern Rock was approaching the Bank of England for emergency funds.

\section{Spillover effects and "Too-big-to-fail"}

The generally higher SND and CDS spreads for the three mortgage banks suggests that the market views the UK banking system as consisting of two tiers: the six multinational banks and the three UK-focused mortgage banks. This distinction is also suggested by the smaller equity trading volumes for the mortgage banks, compared to the multinational banks, and by the fact that the three mortgage banks are the smallest three, measured by assets. As a result, the authors decided to test whether equity investors perceived the announcement that Northern Rock had access to emergency liquidity facilities as a sign that problems would spill over to the larger UK banks or alternatively that Northern Rock and / or the other mortgage and non-mortgage banks may be perceived by investors as TBTF.

This hypothesis was tested using a standard event study methodology and we tested both the abnormal equity returns and abnormal volume of trading for a five-day period surrounding the day $\left(\mathrm{t}=0 ; 14^{\text {th }}\right.$ September2007) when Northern Rock approached the Bank of England and obtained emergency financial support. The 
abnormal equity returns are derived from the one-factor market model estimated over the period $[-260 ;-11]$ using the FTSE All-Share benchmark index. The abnormal volume of trading metric is defined as the difference between the observed turnover ratio and the median turnover ratio through the estimation window. ${ }^{15}$ To analyse whether investors perceived the announcement differently depending on the type of bank, the sample of nine UK banks was partitioned into two sub-samples; the three mortgage banks and the larger "other banks."

The results are presented in table 3. Panel A reports the abnormal equity returns for each of the three mortgage banks, the whole sample of nine banks ("All Listed Banks") and then the two sub-samples of banks over each of the five event days. To understand the findings, it is first appropriate to explain the regulatory authority announcements on each of the event days. As previously explained, $\mathrm{t}=0$ is the day that it was announced that Northern Rock had been granted access to emergency lending facilities. Following the announcement, there was a run on the bank for four days (two days being over the weekend) and including $\mathrm{t}=+1$, namely Monday $17^{\text {th }}$ September. After the close of trading on Monday $17^{\text {th, }}$ and in an attempt to stop the bank run, the government announced an explicit guarantee of all Northern Rock's deposits, which all market commentators also read as an implicit guarantee of all UK bank deposits. Therefore, $\mathrm{t}=+2$ reflects the belief that all UK bank deposits were now fully supported by a government guarantee.

Insert table 3 here 
The event study results clearly suggest that the announcement that Northern Rock had access to emergency lending facilities resulted in statistically significant negative returns for each of the three mortgage banks. This only subsided on day $t=+2$, once the government guarantee had been announced. On that day, the three mortgage banks' shares also reported statistically significant abnormal gains, confirming that investors perceived an implicit guarantee on all banks. Column 6 of Panel A reports the cumulative effect for the three mortgage banks and confirms the preceding equity returns discussion. Column 7 reports the abnormal equity returns for the portfolio of six larger banks. In contrast to the portfolio of mortgage banks, there was no statistically significant abnormal movement in returns on days $\mathrm{t}=0$ and $\mathrm{t}=+1$. This suggests that investors either perceived the larger banks as unlikely to be affected by spillover effects from the Northern Rock crisis or that they are TBTF and so the government will implicitly guarantee them. There was a statistically significant positive movement in abnormal returns on day $\mathrm{t}=+2$ once the government guarantee had been announced. Column 8 compares the abnormal returns in the two subsamples and reports the t-statistics for the difference in average abnormal returns between the two sub-samples. This clearly illustrates that investors perceived the larger banks as unlikely to be affected by the Northern Rock crisis. Whether this is because they are perceived as TBTF is difficult to establish; however, the statistically significant movements in the other mortgage banks does suggest that equity investors were differentiating between mortgage banks and the larger multinational banks and they did not consider the mortgage banks as being TBTF.

Panel B reports abnormal volumes of trading during the event period. The results confirm that investors were differentiating between the two types of bank. Mortgage 
banks witnessed statistically significant abnormal volumes of trading throughout the event period $[0 ;+2]$ whereas the larger "other banks" did not. Again, comparing the difference in average abnormal volume of trading between the two sub-samples confirms that investors were less concerned that the larger banks would be affected by spillover effects from the Northern Rock announcement.

\section{Section 5: Conclusions}

The existing literature on the predictive qualities of market information has found that equity market indicators provide more value far from default, whereas SND yield spreads have a tendency to react close to default. In the Northern Rock context, our results, despite being unable to conduct a logit methodology, suggest similar findings. Equity indicators illustrated a clear negative reaction for Northern Rock compared to peer banks following the profit warning in late June 2007. In contrast, SND spreads and CDS spreads began to indicate clear concerns, if at all, only once the credit crisis had begun, which was only a month before Northern Rock required liquidity assistance. The time-varying estimates of IIVs extracted from option prices clearly deserve further attention in the future because the informational content of this forward-looking indicator appear to be useful to bank supervisors. From a microprudential perspective, the most encouraging result is that the idiosyncratic component represents a substantial portion (more than 70\%) of total IV for a banking firm.

The paper's findings also support the existing market discipline literature in that it can prove difficult to extract clean risk signals from SND spreads and, thus, careful judgement must be exercised when interpreting them [Hancock and Kwast, 2001]. 
This is in part because spreads reflect many dimensions of risk, such that it may be difficult to disentangle the credit risk from other factors. For example, the spread can contain compensation for the different taxation treatment of government and corporate bonds; a liquidity risk component can differ between bonds due to the size of the issue as well as whether it is a recent issue; and finally, yields will reflect not only expected default risk, but also the loss given default. In the case of CDS spreads, the paper has shown that the market is not sufficiently deep in small bank CDS to be able to currently rely on these market signals. Equally, the paper has suggested that there can be conflicting signals between absolute and relative CDS spreads.

From a supervisory perspective, the paper has shown that equity market information may have provided the FSA with some predictive signals of impending default at Northern Rock, whilst SND and CDS spreads only possibly signalled concerns once the FSA was already communicating with the bank. Furthermore, the paper has shown that the supervisory authorities may want to consider equity market analyses that extend beyond their simple share price movements. Equally, the paper highlights the potential benefits to the regulatory authorities in observing a number of early warning metrics concurrently. In so doing, the paper introduces a further metric, implied idiosyncratic volatility and in the Northern Rock case, this metric signalled potential concerns at the same time as the equity market.

The paper also analysed the equity market reactions to the announcement that Northern Rock has access to emergency liquidity facilities. The findings suggest that there were no spillover effects to the larger multinational banks, whereas the smaller mortgage banks did not appear to be perceived as "Too-big-to-fail". 


\section{Appendix 1: Northern Rock - pre-crisis and post crisis}

\section{timeline}

\begin{tabular}{|c|c|}
\hline 24 January 2007 & $\begin{array}{l}\text { Northern Rock releases preliminary results for the year ended } 31 \text { December } \\
2006 \text {. They report record gross and net lending as well as record profitability. } \\
\text { The strategic target for return on equity is increased to } 20 \%-25 \% \text {. The } \\
\text { Northern Rock share price rose } 64 \text { p on the news to close at } 1212 \mathrm{p} \text {. }\end{array}$ \\
\hline 9 February 2007 & Northern Rock shares close at a record $1251 \mathrm{p}$ \\
\hline 31 March 2007 & $\begin{array}{l}\text { Northern Rock reports a regulatory capital position of } 9.74 \% \text {. This is in } \\
\text { breach of the regulatory capital requirement imposed by the FSA by } £ 85.5 \mathrm{~m} \\
\text { or } 0.2 \% \text {. The breach is reported to the FSA in the bank's quarterly capital } \\
\text { filing on } 19 \text { April } 2007 \text {. } \\
\text { The breach is not public knowledge until Northern Rock issues its } 2007 \\
\text { Annual Report and Accounts on } 31 \text { March } 2008 \text {. The FSAs Internal Audit } \\
\text { Division report into the FSAs supervision of Northern Rock released on } 28 \\
\text { April } 2008 \text { also reports the banks breach of capital requirements in March } \\
2007 \text { [FSA, 2008]. The report states: "The breach was rectified by the } \\
\text { disposal of } £ 833 \text { million of secured commercial loans to Lehmans, which was } \\
\text { completed on } 22 \text { June } 2007 \text {, and by the issue of } £ 328 \text { million of subordinated } \\
\text { debt on } 25 \text { June } 2007 . "\end{array}$ \\
\hline 2 April 2007 & $\begin{array}{l}\text { Northern Rock issues a quarterly trading statement indicating that it is on } \\
\text { course for an } 18 \% \text { increase in full-year profit, due to sustained lending growth } \\
\text { and generally benign economic conditions. } \\
\text { The statement also indicates that the bank is continuing moves towards } \\
\text { calculating regulatory capital requirements using the Basel II methodology. } \\
\text { The bank expects to be a major beneficiary of implementing Basel II and it } \\
\text { remains their preference to repatriate initial future and excess capital from } \\
\text { this exercise through increasing dividends }\end{array}$ \\
\hline 26 April 2007 & $\begin{array}{l}\text { The Bank of England issues its latest Financial Stability Report. One of its } \\
\text { discussion points are banks increasing reliance on wholesale funding through } \\
\text { securitisations and how it exposes banks to liquidity-related risks if that } \\
\text { funding was to cease. The report cites the February } 2007 \text { experience in the } \\
\text { US sub-prime indices market. }\end{array}$ \\
\hline 22 June 2007 & $\begin{array}{l}\text { Northern Rock completes the sale of } £ 838 \text { million of its commercial secured } \\
\text { loans to Lehman Brothers and conditionally agrees to sell up to a further } £ 732 \\
\text { million of such loans in the second half of } 2007 \text {. This is publicly announced } \\
\text { in the Stock Exchange Statement released on } 27 \text { June } 2007 \text {. }\end{array}$ \\
\hline 25 June 2007 & $\begin{array}{l}\text { Northern Rock issues } \$ 650 \mathrm{~m}(£ 328 \mathrm{~m} \text { equivalent) of Upper Tier } 2 \\
\text { subordinated debt. This is publicly announced in the Interim Results for the } \\
\text { six months ending } 30^{\text {th }} \text { June } 2007 \text { that is released to the Stock Exchange on } \\
25^{\text {th }} \text { July } 2007 .\end{array}$ \\
\hline 27 June 2007 & $\begin{array}{l}\text { Northern Rock issues a Stock Exchange Statement titled, Pre-close period } \\
\text { statement and Basel II strategic update. This is in effect a warning that its } \\
\text { full-year profit is set to fall short of analysts' forecasts. The statement } \\
\text { highlights the banks' funding mismatch: "Expectations for higher interest } \\
\text { rates in the UK have risen further than anticipated at the time of Northern } \\
\text { Rocks' Q1 Trading Statement on } 2 \text { April } 2007 \text {. Given Northern Rock's Libor- } \\
\text { dominated funding platform, we have a structural mismatch between Libor } \\
\text { and Bank Base Rates and because of changes in the forward interest rate } \\
\text { curve....In times of rising rates this dampens revenue growth with the } \\
\text { opposite occurring as rates fall." } \\
\text { Northern Rock's share price falls almost } 10 \% \text {. }\end{array}$ \\
\hline 29 June 2007 & $\begin{array}{l}\text { Northern Rock is granted a Basel II Internal Ratings Based (IRB) waiver } \\
\text { from the FSA. This enables the bank to calculate regulatory capital } \\
\text { requirements from now on using the Basel II methodology. }\end{array}$ \\
\hline
\end{tabular}




\begin{tabular}{|c|c|}
\hline 25 July 2007 & $\begin{array}{l}\text { Northern Rock releases its Interim results for the six months to } 30 \text { June } 2007 . \\
\text { The Chief Executive reiterates that profits will be impacted by interest rate } \\
\text { movements: "The outlook for the full year is being impacted by sharp } \\
\text { increases in money market and swap rates seen in the first half. This has } \\
\text { resulted in a negative impact on net interest income as mortgage pricing in the } \\
\text { market generally has lagged behind increases in funding costs in the year to } \\
\text { date." } \\
\text { The bank reports its interim regulatory capital position under the newly } \\
\text { granted Basel II methodology. The bank states: "The implementation of Basel } \\
\text { II results in our ... risk-weighted assets at } 30 \text { June } 2007 \text { falling from around } \\
£ 33.9 \text { billion under Basel I to } 18.9 \text { billion under Basel II". Furthermore, the } \\
\text { bank reiterates its intention to release surplus capital: "The introduction of } \\
\text { Basel II, together with the planned disposal of capital inefficient assets and } \\
\text { continued capital management...results in an anticipated regulatory capital } \\
\text { surplus over the next } 3 \text { to } 4 \text { years. This surplus will enable the reduction of } \\
\text { previously planned subordinated debt issues and permit capital repatriation of } \\
\text { up to £300 to £400 million over this period". The bank also states: "The } \\
\text { introduction of Basel II, which requires less capital to support new lending, } \\
\text { also enables a review of the company's dividend policy. The interim dividend } \\
\text { therefore increases by } 30.3 \% \text { to } 14.2 p \text { payable on } 26 \text { October } 2007 . " \\
\text { Nevertheless, five days before the half-year end period Northern Rock issues } \\
£ 328 \text { million of Upper Tier } 2 \text { subordinated debt. Although analysts do not } \\
\text { know what the FSAs individual capital requirement is for each bank, an astute } \\
\text { analysis of the interim statement would have shown that without the issuance } \\
\text { of the Upper Tier } 2 \text { capital, the sale of commercial secured loans to Lehman } \\
\text { Brothers and the Basel II waiver (all of which happened in the final week of } \\
\text { June) Northern Rock's regulatory capital position using the existing Basel I } \\
\text { methodology may well have been below } 10 \% \text {; a potentially worrying sign. }\end{array}$ \\
\hline 26 July 2007 & $\begin{array}{l}\text { The FTSE } 100 \text { drops } 3.14 \% \text { as concerns over the US sub-prime crisis } \\
\text { intensify. }\end{array}$ \\
\hline 9 August 2007 & $\begin{array}{l}\text { The European Central Bank, the US Federal Reserve and Bank of Japan } \\
\text { pump unprecedented amounts of liquidity into the financial system to allay } \\
\text { fears about a credit crunch. This represents the start of numerous actions by } \\
\text { central banks into the money markets to shore up confidence in the financial } \\
\text { system. }\end{array}$ \\
\hline 10 August 2007 & $\begin{array}{l}\text { The FTSE } 100 \text { suffers its worst one-day fall }(3.7 \%) \text { for more than four years. } \\
\text { Northern Rock shares fall } 9.6 \% \text {, down almost } 40 \% \text { this year and } \\
\text { consolidating its position as the worst performing blue-chip stock of the year. }\end{array}$ \\
\hline 16 August 2007 & The FTSE 100 drops a further $4.1 \%$ \\
\hline 20 August 2007 & $\begin{array}{l}\text { Northern Rock completes the disposal of } £ 465 \text { million of commercial secured } \\
\text { loans to Lehman Brothers. }\end{array}$ \\
\hline 14 September 2007 & $\begin{array}{l}\text { The Tripartite Authorities announce that the Bank of England is providing } \\
\text { Lender of Last Resort emergency funding facilities to Northern Rock to allow } \\
\text { it to continue operating. Under the open-ended facility, the bank is charged a } \\
\text { penal rate and can use mortgages and mortgage-backed securities as } \\
\text { collateral. }\end{array}$ \\
\hline 17 September 2007 & $\begin{array}{l}\text { HM Treasury announce a full guarantee of Northern Rock's existing deposits } \\
\text { in an attempt to stem the deposit run on the bank and restore financial } \\
\text { confidence. }\end{array}$ \\
\hline 21 September 2007 & $\begin{array}{l}\text { Confirmed that Northern Rock had borrowed around } £ 3 \text { billion from the Bank } \\
\text { of England under the emergency funding facility. }\end{array}$ \\
\hline 24 September 2007 & $\begin{array}{l}\text { Northern Roc bows to political pressure and cancels its proposed } £ 59 \text { million } \\
\text { dividend payout. }\end{array}$ \\
\hline 27 September 2007 & $\begin{array}{l}\text { Announced that Northern Rock's debt to the Bank of England is now } £ 8 \\
\text { billion. }\end{array}$ \\
\hline 4 October 2007 & $\begin{array}{l}\text { Announced that Northern Rock’s indebtedness to the Bank of England now } \\
\text { stands at around } £ 11 \text { billion. }\end{array}$ \\
\hline 9 October 2007 & $\begin{array}{l}\text { HM Treasury extends the full deposit guarantee to new depositors of } \\
\text { Northern Rock. }\end{array}$ \\
\hline
\end{tabular}




\begin{tabular}{|c|c|}
\hline 11 October 2007 & $\begin{array}{l}\text { Revealed that Northern Rock's indebtedness to the Bank of England now } \\
\text { stands at around } £ 13 \text { billion. The emergency facility conditions are relaxed } \\
\text { allowing Northern Rock to use any collateral to access the Bank of England's } \\
\text { lifeline. }\end{array}$ \\
\hline 18 October 2007 & $\begin{array}{l}\text { Revealed that Northern Rock’s indebtedness to the Bank of England has risen } \\
\text { to } 16 \text { billion. }\end{array}$ \\
\hline 19 October 2007 & The chairman of Northern Rock resigns. \\
\hline 16 November 2007 & $\begin{array}{l}\text { The Chief Executive of Northern Rock announces that he will resign in } \\
\text { January 2008, once the bank has completed the second phase of its strategic } \\
\text { review. }\end{array}$ \\
\hline 13 December 2007 & The Chief Executive of Northern Rock resigns. \\
\hline 31 March 2008 & $\begin{array}{l}\text { The Annual Reports and Accounts state that Northern Rock's indebtedness to } \\
\text { the Bank of England was } £ 27 \text { billion at } 31 \text { December } 2007 \text {. }\end{array}$ \\
\hline 11 January 2008 & $\begin{array}{l}\text { Northern Rock agrees to sell } 2 \% \text { of its mortgage assets to JP Morgan. The } \\
\text { funds are used to repay some of the emergency loan provided by the Bank of } \\
\text { England. }\end{array}$ \\
\hline 17 February 2008 & $\begin{array}{l}\text { The Chancellor of the Exchequer announces that neither of the two remaining } \\
\text { private sector bids for Northern Rock offer enough value to the taxpayer, and } \\
\text { therefore the bank will be temporarily nationalised. }\end{array}$ \\
\hline 18 February 2008 & Northern Rock shares are suspended on the London Stock Exchange. \\
\hline
\end{tabular}

Sources: Authors and Hall (2007) 


\section{Appendix 2: The Implied Idiosyncratic Volatility (IIV) metric}

This appendix briefly describes the technical details behind the procedure used to compute the Implied Idiosyncratic Volatility (IIV) metric discussed in the paper. Following the previous literature on implied volatility dynamics, we use two methods to estimate the individual bank stock's IIV: the first one is based on the variance decomposition implied by the market model, while the second method uses a decomposition of the implied market variance based on the discrete-time version of the Ornstein-Uhlenbeck stochastic process.

\section{A2.1 IIV estimates based on the market model decomposition of total variance}

The procedure consists in estimating the market model parameters for each bank by regressing the daily (log-differenced) stock return for the relevant bank security, $R_{i t}$, upon the corresponding broad market return (FTSE100), $R_{m i}$ :

$$
R_{i t}=\alpha_{i t}+\beta_{i t} R_{m t}+\epsilon_{i t}
$$

The market model parameters, $\alpha_{i t}$ and $\beta_{i t}$, are estimated over 250-day "rolling" windows before each day from January $1^{\text {st }}$ through December $31^{\text {st }}, 2007$. We retain the time-varying beta coefficient estimates and compute the IIV measures for each bank $i$, each day $t$, using the variance decomposition implied by the market model:

$$
I V V_{i t}=\sqrt{I V_{i t}^{2}-\beta_{i t}^{2} I V_{m i t}^{2}}
$$

where $I V_{i t}$ is bank $i$ 's implied idiosyncratic volatility on day $t, W_{i t}^{2}$ is bank $i$ 's total implied variance, $\hat{\beta}_{i t}$ is bank $i$ 's time-varying beta coefficient estimate, and $V_{m t}^{2}$ is the standardized implied variance of FTSE100, i.e. the equity volatility index for the UK. For some days, the quantity inside the square root computed in this manner takes negative values; in these exceptional cases, we derive the IIV measure by 
interpolating between the previous day's estimate and the subsequent day's value of IIV, which are both positive.

\section{A2.2 IIVs derived from the Ornstein-Uhlenbeck representation of market volatility}

To extract the idiosyncratic component of IV using the Ornstein-Uhlenbeck representation of market volatility, we start by expressing the standardized implied variance of the UK index FTSE100 as an arithmetic mean reverting process:

$$
d V_{m}^{2}=\eta\left(\mu-I V_{m}^{2}\right) d t+\sigma d B_{t}
$$

where $\mu$ is the long-run equilibrium level (i.e. the long-run mean which the volatility series tends to revert), $\eta$ is the constant speed of reversion, $\sigma$ is the instantaneous volatility parameter, and $d B_{t}$ denotes the increment of the Gauss-Wiener process, $d B_{t}=\phi_{t} \sqrt{d t}$, with $\phi_{t} \sim \mathcal{N}(0,1)$

The equation describing the continuous-time dynamics of implied variance presented above can easily be rewritten, in its discrete time version, as follows:

$$
\Delta I V_{m i}^{2} \equiv I V_{m i}^{2}-I V_{m, t-1}^{2}=\mu\left(1-e^{-\eta \Delta t}\right)+\left(e^{-\eta \Delta t}-1\right) I V_{m, t-1}^{2}+\epsilon_{t}
$$

where $\epsilon_{\mathrm{t}} \sim \mathcal{N}\left(0, \sigma_{\varepsilon}^{2}\right)$ and $\sigma_{\varepsilon}^{2}=\left(1-e^{-2 \eta}\right) \sigma^{2} / 2 \eta$. Within the particular context of our application, we run the following regression, which is the well-known first-order autoregressive process $\mathrm{AR}(1)$, to estimate the parameters of the mean-reversion process:

$$
\Delta V_{m i}^{2}=\varphi+\psi V_{m, t-1}^{2}+\epsilon_{t}
$$

It is straightforward to show that $\mu=-\varphi / \psi, \eta=-l n(1+\psi)$, and $\sigma=\sigma_{\varepsilon} \sqrt{2 \ln (1+\psi) /\left[(1+\psi)^{2}-1\right]}$, where $\sigma_{\varepsilon}$ is the standard deviation of the residual error term and $\sigma$ is the instantaneous volatility parameter of the meanreversion process. 
Finally, using the estimated mean-reversion parameters and the same variance decomposition implied by the market model, we compute the IIV measures for each bank $i$, each day $t$ as follows:

$$
H V_{i t}=\sqrt{I V_{i t}^{2}-\beta_{i t}^{2}\left\{I V_{m, t-1}^{2}+\mathbb{E}\left[\Delta V_{m:}^{2} \mid I V_{m, t-1}^{2}\right]\right\}}
$$

where $\hat{\beta}_{i \text { t }}^{2}$ is bank $i$ 's time-varying beta coefficient estimate using a 250 -day rolling window ending on day $t-1$ and $\mathbb{E}\left[\Delta I V_{m t}^{2} \mid V_{m, t-1}^{2}\right]=\hat{\varphi}+\widehat{\psi} V_{m, t-1}^{2}$, i.e. the change in implied variance of the UK index FTSE100 predicted by the discrete-time form of the mean-reversion process.

As in the previous case, the quantity inside the square root computed in this manner may exceptionally take negative values. If it is the case, we derive the IIV measure by interpolating between the previous day's estimate and the subsequent day's value of IIV, which are both positive. 


\section{References}

Berger, A. (1991), "Market Discipline in Banking”, Proceedings of a Conference on

Bank Structure and Competition, Federal Reserve Bank of Chicago, May, pp. 419-437.

Berger, A. and Davies, S. (1998), "The Information Content of Bank Examinations", Journal of Financial Services Research, Vol. 14:2, pp. 117-144.

Berger, A., Davies, S. and Flannery, M. (2000), 'Comparing Market and Supervisory Assessments of Bank Performance: Who Knows What When?' Journal of Money, Credit and Banking, Vol. 32, pp. 641-667.

Birchler, U. and Facchinetti, M. (2007), "Can Bank Supervisors Rely on Market Data? A Critical Assessment from a Swiss Perspective", Swiss Journal of Economics and Statistics, Vol. 143, pp. 95-132.

Black, F. and Scholes, M. (1973), "The Pricing of Options and Corporate Liabilities", Journal of Political Economy, Vol. 3, pp. 637-654.

Bliss, R. (2001), "Market Discipline and Subordinated Debt: A Review of Some Salient Issues", Federal Reserve Bank of Chicago Economic Perspectives, 1st Quarter, pp. 24-45.

Brown, S. and Warner, J. (1985), "Using Daily Stock Returns: The Case of Event Studies”, Journal of Financial Economics, Vol. 14, pp. 3-31.

Canina, L. and Figlewsky, S. (1993), “The Information Content of Implied Volatility", Review of Financial Studies, Vol. 6, pp. 659-681.

Christensen, B. and Prabhala, N. (1998), “The Relation Between Implied and Realized Volatility”, Journal of Financial Economics, Vol. 50, pp. 125-150.

Croft, J. and Tett, G. (2007), “The Rock needs to reassess its strategy”, Financial Times, June $28^{\text {th }}$.

Crosbie, P. and Bohn, J. (2003), "Modeling Default Risk”, Available at: http://www.defaultrisk.com, Moodys KMV.

Cole, R. and Gunther, J. (1998), 'Predicting Bank Failures: A Comparison of On- and Off-Site Monitoring Systems', Journal of Financial Services Research, Vol. 13:2, pp. 103-117.

Cox, J., Ross, S. and Rubinstein, M. (1979), “Options Pricing: A Simplified Approach", Journal of Financial Economics, Vol. 7, pp. 229-263. 
Dennis, P., Mayhew, S. and Stivers, C. (2006), "Stock Returns, Implied Volatility Innovations, and the Asymmetric Volatility Phenomenon", Journal of Financial and Quantitative Analysis, Vol. 41, pp. 381-406.

DeYoung, R., Flannery, M., Lang, W. and Sorescu, S. (2001), “The Information Content of Bank Exam Ratings and Subordinated Debt Prices", Journal of Money, Credit and Banking, Vol. 33, pp. 900-925.

Diavatopoulos, D., Doran, J. and Peterson, D. (2008), “The Information Content in Implied Idiosyncratic Volatility and the Cross-Section of Stock Returns: Evidence from the Option Markets", Journal of Futures Markets, forthcoming. European Central Bank (2004), Financial Stability Review, European Central Bank, December.

European Central Bank (2005), "Bank Market Discipline”, Monthly Bulletin (February), European Central Bank, pp. 55-64.

Evanoff, D. and Wall, L. (2001a), "Reforming Bank Capital Regulation: Using Subordinated Debt to Enhance Market and Supervisory Discipline", Contemporary Economic Policy, Vol. 19, pp. 444-453.

Evanoff, D. and Wall, L. (2001b), "Sub-Debt Yield Spreads as Bank Risk Measures”, Journal of Financial Services Research, Vol. 20:2/3, pp. 121-145.

Evanoff, D. and Wall, L. (2003), "Subordinated Debt and Prompt Corrective Regulatory Action”, Federal Reserve Bank of Chicago, Working Paper, No. 2003-03.

Financial Services Authority (2008), “The Supervision of Northern Rock: a lessons learned review", Report, Financial Services Internal Audit Division, March. Flannery, M. (1998), 'Using Market Information in Prudential Bank Supervision: A Review of the U.S. Empirical Evidence', Journal of Money, Credit and Banking, Vol. 30, pp. 273-305.

Flannery, M. and Sorescu, S. (1996), 'Evidence of bank market discipline in subordinated debenture yields: 1983-1991', Journal of Finance, Vol. 51, pp. 1347-1377.

Flannery, M. and Nikolova, S. (2003), 'Market Discipline of US Financial Firms: Recent Evidence and Research Issues'. In C. Borio, W. Hunter, G. Kaufman and K. Tsatsaronis, (eds.), Market Discipline across Countries and Industries, MIT Press: Cambridge, Mass, pp. 87-100. 
Furlong, F. and Williams R. (2006), "Financial Market Signals and Banking Supervision: Are Current Practice Consistent with Research Findings?" Federal Reserve Bank of San Francisco Economic Review, pp. 17-29.

Gropp, R., Vesala, J. and Vulpes, G. (2006), "Equity and Bond Market Signals as Leading Indicators of Bank Fragility", Journal of Money, Credit and Banking, Vol. 38, pp. 399-428.

Hall, M. (2007), “The sub-prime crisis, the credit squeeze and Northern Rock: the lessons to be learned", Journal of Financial Regulation and Compliance, Vol. 16, pp. 19-34.

Hamalainen, P. (2007), “Assessing Market Discipline in UK Credit Institutions:

Subordinated Debt Holders as Signallers of Bank Risk", PhD Thesis, Loughborough University, Loughborough.

Hamalainen, P., Hall, M. and Howcroft, J. (2003), "Market Discipline: A Theoretical Framework for Regulatory Policy Development”. In G. Kaufman (ed.) Market Discipline in Banking: Theory and Evidence, Research in Financial Services, Vol. 15, pp. 57-97.

Hamalainen, P., Howcroft, J. and Hall, M., (2007), "Market discipline in UK credit institutions: an empirical analysis of subordinated debt holders as signallers of bank risk", Conference Paper, Tor Vergata Conference on Banking and Finance, Rome, December.

Hamalainen, P., Howcroft, J. and Hall, M., (2008), "Should a Mandatory

Subordinated Debt Policy be introduced for the UK? Evidence from the issuance activity of banks and building societies", Contemporary Economic Policy, forthcoming.

Hill, A. (2007a), “Northern Rock's model no longer looks as solid”, Financial Times, June $28^{\text {th }}$.

Hill, A. (2007b), "Rock faces a hard climb", Financial Times, August $16^{\text {th }}$.

House of Commons Treasury Committee (2008), The run on the Rock, Fifth Report of Session 2007-08, Vol. I, January.

Hughes, C. (2007), “Time for Alliance \& Leicester to build on its safe legacy”, Financial Times, February $22^{\text {nd }}$.

Hume, N. (2007), “Northern Rock still dogged by concerns over interbank rate”, Financial Times, September $4^{\text {th }}$. 
Jagtiani, J. and Lemieux, C. (2001), "Market Discipline prior to bank failure", Journal of Economics and Business, Vol. 53, pp. 313-324.

Krainer, J. and Lopez, J. (2004), “Incorporating Equity Market Information into Supervisory Monitoring Models", Journal of Money, Credit, and Banking, Vol. 36, pp. 1043-1068.

Merton, R. (1974), “An analytical Derivation of the Cost of Deposit Insurance and Loan Guarantees", Journal of Banking and Finance, Vol. 1, pp. 3-11.

Mayhew, S. (1995), “Implied Volatility”, Financial Analysts Journal, Vol. 54, pp. 819.

Mayhew, S. and Stivers, C. (2003), "Stock Return Dynamics, Option Volume, and the Information Content of Implied Volatility", Journal of Futures Markets, Vol. 23, pp. 615-646.

Mikkelson, W. and Partch, M. (1988), "Withdrawn Security Offerings”, Journal of Financial and Quantitative Analysis, Vol. 23, pp. 119-133.

Northern Rock (2007a), “2006 preliminary results announcement”, London Stock Exchange announcement, January $24^{\text {th }}$.

Northern Rock (2007b), “2007 Trading Statement - 3 months to 31 March 2007”, London Stock Exchange announcement, April $2^{\text {nd }}$.

Northern Rock (2007c), "Pre-Close Period Statement and Basel II Strategic Update", London Stock Exchange announcement, June $27^{\text {th }}$.

Northern Rock (2007d), “2007 Interim Results”, London Stock Exchange announcement, July $25^{\text {th }}$.

Northern Rock (2007e), "Statement on market conditions and trading update", London Stock Exchange announcement, September $14^{\text {th }}$.

Northern Rock (2008), Annual Reports and Accounts for the year ended $31^{\text {st }}$ December 2007.

Persson, M. and Blåvarg, M. (2003), 'The Use of Market Indicators in Financial Stability Analysis', Economic Review, Sveriges Riksbank, Vol. 2, pp. 5-28. Schmidt, J. (2004), "A Review of the Use of Market Data in the Federal Reserve System", Conference paper, Supervisory Use of Market Data, Federal Reserve Bank of Cleveland, Cleveland, March.

Sironi, A. (2003), “Testing for Market Discipline in the European Banking Industry: Evidence from Subordinated Debt Issues", Journal of Money, Credit and Banking, Vol. 35, pp. 443-472. 
Swidler, S. and Wilcox, J. (2002), “Information about Bank Risk in Options Prices”, Journal of Banking and Finance, Vol. 26, pp. 1033-1057.

Thal Larsen, P. (2007a), “Northern Rock acts on funding fears”, Financial Times, August $16^{\text {th }}$.

Thal Larsen, P. (2007b), “The Rock’s strategy called into question”, Financial Times, August $16^{\text {th }}$.

US Shadow Financial Regulatory Committee (2000), "Reforming bank capital regulation", Policy Statement, No. 160, Washington: AEI Press.

${ }^{1}$ However, the debate between equity and SND signals is still very much open because: (1) extracting relevant information from credit spreads may be a difficult task (liquidity premia are often excessively volatile and other technical factors besides default risk may influence credit spreads); (2) (sub-)debt markets are less liquid, active and deep than equity markets; and (3) debtholders' incentives to monitor may be affected by the perception of TBTF-type guarantees or other (governmental) guarantees

${ }^{2}$ The distance to default combines stock price information with stock volatility and leverage, and measures the number of standard deviations away from default, where default is defined as the point at which assets are just equal to liabilities. This property makes the distance to default a useful indicator from a supervisory perspective.

${ }^{3}$ See the discussion in Bliss (2001, pp. 33-36). This intuition can be illustrated using relatively simple numerical simulations. We should like to thank Robert Bliss for explaining to us in great detail how to conduct the numerical simulations.

${ }^{4}$ The report does identify a further and related weakness, staff expertise: "partly because of turnover, the FSA is short of expertise in some fundamental areas, notably prudential banking expertise and financial data analysis."

${ }^{5}$ The weaknesses in supervisory teams obtaining and analysing data do not appear to have been restricted to external sources of information. The report also lists as a desired outcome: "Regulatory returns for a firm and its peers should be easily accessible to supervisors and should be used to input to the on-going assessment of the firms."

${ }^{6}$ Notably, Northern Rock's 2006 Annual Reports and Accounts reported that interest margins were down on 2005 due to a widening gap between 3 Month Libor and the Bank Base Rate, especially in the second half of 2006.

${ }^{7}$ Subsequently, the House of Commons Treasury Select Committee's investigation into the Northern Rock crisis has shown that the seizure in funding markets on $9^{\text {th }}$ August 2007 prompted the Financial Services Authority to contact Northern Rock, because it perceived the bank to be at risk from the freezing of financial markets. Thereafter the Financial Services Authority and Northern Rock were in daily telephone contact. Soon afterwards all parties in the Tripartite Committee were in constant 
contact with Northern Rock to devise a strategy to extricate Northern Rock from its difficulties. [HM Treasury Committee, 2008]

${ }^{8}$ The UK government's “rescue" of Northern Rock depositors on $17^{\text {th }}$ September 2007 does suggest a possible policy shift, but the government's guarantee arrangements explicitly state that subordinated debt instruments are excluded.

${ }^{9}$ The eight banks comprise of: HSBC; Barclays; RBS; HBOS; Lloyds; Standard Chartered; Bradford \& Bingley; and Alliance \& Leicester. The last two banks, along with Northern Rock, are informally distinguished from the other six through the term "mortgage banks" because they were originally mutual building societies and most of their business still revolves around housing loans. These three banks are also the smallest ones in the sample.

${ }^{10}$ However, the view that IV measures clearly dominate volatility estimates based on historical return data has not reached consensus in the literature. For instance, Canina and Figlewsky (1993) found that the S\&P index IV contains little information regarding future volatility and, hence, has almost no predictive power in forecasting future volatility. So, they conclude that IV is an inefficient and biased forecast of future volatility. This atypical empirical result may be attributed to data limitations and sampling procedures (for further discussion, see Christensen and Prabhala, 1998).

${ }^{11}$ This is the official settled price issued by the exchange at closing of the day session. If the official settlement price is not reported by the exchange on a particular day, then the closing price will be stored as exchange definition. In this exceptional case, the close may be derived from last trade, last mid bid/ask price, last lowest ask or highest bid price.

${ }^{12}$ The methodology used in the present study mirrors the volatility indices methodology used in the market place. Many volatility indices (e.g. VIX, the implied volatility on the S\&P 500 index option, or the VDAX index disseminated by Deutsche Börse) take into account a number of eight options, including a Call and a Put at the two strike prices closest to the money and the nearest two expirations. Hence, our IV measure is slightly lower because the methodology we used is based on the "at the money" implied volatility interpolated between only two options (one strike above and one bellow the underlying price).

${ }^{13}$ To our knowledge, this is the first paper that proposes the use of idiosyncratic implied volatilities as a bank risk metric for supervisory purposes. Swidler and Wilcox (2006) also advocate for the use of IVs to improve the regulatory oversight of banks, but they do not break down total IV in order to extract the idiosyncratic component.

${ }^{14}$ Across our sample, we observed only 12 occurrences where the estimated implied idiosyncratic variance has negative values. In these exceptional cases, we replace the negative value by the interpolated value between the previous day's estimate and the subsequent day's value of IIV, which are both positive.

${ }^{15}$ The turnover ratio is calculated as the daily volume of trading expressed as the logarithm of the percentage of the number of outstanding shares that is traded on a given day. 
Table 1. Option Contracts on UK Listed Banks' Stocks traded on LIFFE: Descriptive Statistics

\begin{tabular}{lcccc}
\hline \multicolumn{1}{c}{ Bank } & $\begin{array}{c}\text { Option ticker } \\
\text { symbol }\end{array}$ & $\begin{array}{c}\text { Option series } \\
\text { live in Sept. 2007 } \\
\text { (CALL/PUT) }\end{array}$ & $\begin{array}{c}\text { Open interest } \\
\mathbf{2 6 / 0 6 - 1 4 / 0 9} \\
\text { (CALL/PUT) }\end{array}$ & $\begin{array}{c}\text { Trading volume } \\
\mathbf{2 6 / 0 6 - 1 4 / 0 9} \\
\text { (CALL/PUT) }\end{array}$ \\
\hline \hline Alliance \& Leicester & LEI & $15 / 15$ & $2660.2 / 3442.2$ & $75.5 / 81.0$ \\
Barclays & BBL & $77 / 77$ & $102009.8 / 114050.7$ & $604.4 / 1158.2$ \\
HBOS & HAX & $57 / 57$ & $7207.5 / 15208.8$ & $183.5 / 410.5$ \\
HSBC & HSB & $89 / 89$ & $129309.3 / 203796.0$ & $499.0 / 1144.4$ \\
Lloyds & TSB & $73 / 73$ & $39581.1 / 53864.4$ & $370.1 / 410.8$ \\
Northern Rock & NKR & $30 / 30$ & $3217.5 / 23418.3$ & $70.5 / 133.0$ \\
Royal Bank of Scotland & RBS & $152 / 152$ & $21074.5 / 50568.8$ & $293.9 / 589.2$ \\
Standard Chartered & SCB & $21 / 21$ & $5558.8 / 4565.4$ & $53.4 / 97.5$ \\
\hline
\end{tabular}

This table provides descriptive statistics on key variables characterizing the option contracts on UK listed banks' stocks traded on LIFFE in 2007: (i) option ticker symbol; (ii) number of different option series (Call/Put, option type, expiry dates, strike prices...) "live" in September 2007, i.e. issued at least 22 trading days before September $14^{\text {th }}$ and expiring after September $21^{\text {st }}$, the date after which expiring option classes stop trading (all options included in our sample belong to the March/MJSD cycle); (iii) total number of option contracts (Call/Put) that were "opened" on average after release of the profit warning on June $26^{\text {th }}$ and before September $14^{\text {th }}$, i.e. contracts that were traded but not yet liquidated (total "open interest" of all Put or Call options for the day for all expiry months); (iv) daily volume of traded contracts or "market breadth" between June $26^{\text {th }}$ and September $14^{\text {th }}$, i.e. the total turnover of all Puts or Calls for the day for all expiry months

Source: authors' computations based on data provided by Reuters/Thomson Financial 
Table 2. Implied Volatility (IV) \& Implied Idiosyncratic Volatility (IIV) Estimates

\begin{tabular}{|c|c|c|c|c|c|c|c|c|c|c|}
\hline \multirow{3}{*}{ Bank } & \multicolumn{5}{|c|}{ Implied Volatility (IV) } & \multicolumn{5}{|c|}{ Implied Idiosyncratic Volatility (IIV) } \\
\hline & \multicolumn{5}{|c|}{$26 / 06-14 / 09$} & \multicolumn{5}{|c|}{ 26/06-14/09 } \\
\hline & Mean & Median & Std. dev. & Min & Max & Mean & Median & Std. dev. & Min & Max \\
\hline Alliance \& Leicester & $34.47 \%$ & $34.57 \%$ & $3.58 \%$ & $23.07 \%$ & $41.77 \%$ & $27.02 \%$ & $26.67 \%$ & $2.84 \%$ & $16.51 \%$ & $34.86 \%$ \\
\hline Barclays & $32.71 \%$ & $32.43 \%$ & $5.09 \%$ & $24.28 \%$ & $42.79 \%$ & $19.80 \%$ & $20.53 \%$ & $3.85 \%$ & $12.19 \%$ & $28.09 \%$ \\
\hline HBOS & $30.12 \%$ & $27.39 \%$ & $8.25 \%$ & $21.74 \%$ & $47.45 \%$ & $21.19 \%$ & $16.77 \%$ & $7.85 \%$ & $10.11 \%$ & $39.47 \%$ \\
\hline $\mathrm{HSBC}$ & $19.93 \%$ & $20.36 \%$ & $3.54 \%$ & $13.98 \%$ & $29.30 \%$ & $14.72 \%$ & $14.43 \%$ & $2.78 \%$ & $9.08 \%$ & $22.55 \%$ \\
\hline Lloyds & $25.86 \%$ & $25.31 \%$ & $2.57 \%$ & $20.74 \%$ & $32.46 \%$ & $18.89 \%$ & $19.07 \%$ & $2.86 \%$ & $10.93 \%$ & $23.84 \%$ \\
\hline Northern Rock & $39.33 \%$ & $37.49 \%$ & $11.80 \%$ & $26.69 \%$ & $70.77 \%$ & $28.09 \%$ & $25.06 \%$ & $10.41 \%$ & $8.79 \%$ & $63.64 \%$ \\
\hline Royal Bank of Scotland & $29.77 \%$ & $29.86 \%$ & $5.04 \%$ & $22.14 \%$ & $38.60 \%$ & $21.47 \%$ & $20.62 \%$ & $2.65 \%$ & $16.99 \%$ & $29.54 \%$ \\
\hline Standard Chartered & $28.96 \%$ & $29.12 \%$ & $3.40 \%$ & $24.93 \%$ & $36.95 \%$ & $13.72 \%$ & $15.06 \%$ & $4.30 \%$ & $4.00 \%$ & $19.48 \%$ \\
\hline
\end{tabular}

This table describes the statistical distribution (mean, standard deviation, minimum, and maximum over the period June $26^{\text {th }}-$ September $14^{\text {th }}$ ) of our two measures of volatility implied by the market prices of the options contracts on UK listed banks' stocks: Total Implied Volatility (IV) and Implied Idiosyncratic Volatility (IIV). We infer a "standardized" measure of IV based on the nearest two "at-the-money" options series -- one above and one below the underlying price -- using values from the nearest expiry month options (the options series switches to the next available month on the first day of the expiry month). We next interpolate between the two IVs to calculate an estimate of the IV for a hypothetically "at-the-money" Call/Put option. Finally, we average the IVs of the two (Call and Put) option contracts to obtain the IV for options with the strike price nearest to the underlying bank stock price. As all option contracts on UK listed banks' stocks traded on LIFFE are American-type options, the IVs are computed using the Cox-Ross-Rubinstein binomial tree model to take into account the possibility of early exercise. To compute the idiosyncratic component of implied volatility (IIV), we use a decomposition of the total implied variance based on the discrete time version of the Ornstein-Uhlenbeck stochastic process, which takes into account the mean-reversion behavior of IV (see Appendix 2). As a benchmark for the option market volatility and sentiment, we use the implied volatility on the FTSE 100 index options, calculated in the same manner as the individual bank's IVs, from both Calls and Puts that are near the money.

Source: authors' computations based on data extracted from Reuters 3000 Xtra and Datastream Thomson Financial 
Table 3. Stock Market Reaction to the Decision Made by the Bank of England to grant emergency liquidity facilities to Northern Rock on September $14^{\text {th }}, 2007$

\begin{tabular}{|c|c|c|c|c|c|c|c|}
\hline $\begin{array}{c}\text { Day / } \\
\text { Window }\end{array}$ & $\begin{array}{l}\text { Northern } \\
\text { Rock }\end{array}$ & $\begin{array}{l}\text { Alliance \& } \\
\text { Leicester }\end{array}$ & $\begin{array}{l}\text { Bradford } \\
\text { \& Bingley }\end{array}$ & $\begin{array}{l}\text { All Listed } \\
\text { Banks }\end{array}$ & $\begin{array}{l}\text { Mortgage } \\
\text { Banks }\end{array}$ & $\begin{array}{l}\text { Other } \\
\text { Banks }\end{array}$ & $\begin{array}{c}\text { Mortgage vs. } \\
\text { Other }\end{array}$ \\
\hline \multicolumn{8}{|c|}{ Panel A: Abnormal equity returns } \\
\hline-2 & $\begin{array}{l}-0.31 \% \\
(-0.22)\end{array}$ & $\begin{array}{l}-0.92 \% \\
(-0.84)\end{array}$ & $\begin{array}{l}1.39 \% \\
(1.27)\end{array}$ & $\begin{array}{l}-0.22 \% \\
(-0.41)\end{array}$ & $\begin{array}{l}0.05 \% \\
(0.06)\end{array}$ & $\begin{array}{l}-0.36 \% \\
(-0.70)\end{array}$ & 0.16 \\
\hline-1 & $\begin{array}{l}-5.87 \% \\
(-4.13)^{* * *}\end{array}$ & $\begin{array}{l}-3.47 \% \\
(-3.16)^{* * *}\end{array}$ & $\begin{array}{l}-0.68 \% \\
(-0.62)\end{array}$ & $\begin{array}{l}-1.51 \% \\
(-2.83)^{* * *}\end{array}$ & $\begin{array}{l}-3.34 \% \\
(-3.70)^{* * *}\end{array}$ & $\begin{array}{l}-0.59 \% \\
(-1.16)\end{array}$ & -1.08 \\
\hline 0 & $\begin{array}{c}-35.63 \% \\
(-25.02)^{* * *}\end{array}$ & $\begin{array}{l}-5.68 \% \\
(-5.15)^{* * *}\end{array}$ & $\begin{array}{l}-6.28 \% \\
(-5.70)^{* * *}\end{array}$ & $\begin{array}{c}-5.60 \% \\
(-10.46)^{* * *}\end{array}$ & $\begin{array}{l}-15.86 \% \\
(-17.52)^{* * *}\end{array}$ & $\begin{array}{l}-0.47 \% \\
(-0.91)\end{array}$ & $-6.07^{* * *}$ \\
\hline+1 & $\begin{array}{c}-40.95 \% \\
(-28.67)^{* * *}\end{array}$ & $\begin{array}{c}-35.56 \% \\
(-32.10)^{* * *}\end{array}$ & $\begin{array}{l}-14.42 \% \\
(-13.06)^{* * *}\end{array}$ & $\begin{array}{l}-10.64 \% \\
(-19.80)^{* * *}\end{array}$ & $\begin{array}{l}-30.31 \% \\
(-33.37)^{* * *}\end{array}$ & $\begin{array}{l}-0.80 \% \\
(-1.55)\end{array}$ & $-11.63^{* * *}$ \\
\hline+2 & $\begin{array}{c}5.98 \% \\
(4.19)^{* * *} \\
\end{array}$ & $\begin{array}{c}26.35 \% \\
(23.85)^{* * *} \\
\end{array}$ & $\begin{array}{c}4.17 \% \\
(3.79)^{* * *}\end{array}$ & $\begin{array}{c}5.03 \% \\
(9.40)^{* * *}\end{array}$ & $\begin{array}{c}12.16 \% \\
(13.43)^{* * *}\end{array}$ & $\begin{array}{c}1.47 \% \\
(2.86)^{* * *}\end{array}$ & $4.21^{* * *}$ \\
\hline$[-2 ;-1]$ & $\begin{array}{c}-6.17 \% \\
(-3.08)^{* * *}\end{array}$ & $\begin{array}{c}-4.40 \% \\
(-2.83)^{* * *}\end{array}$ & $\begin{array}{l}0.71 \% \\
(0.46)\end{array}$ & $\begin{array}{c}-1.73 \% \\
(-2.29)^{* * *}\end{array}$ & $\begin{array}{c}-3.29 \% \\
(-2.58)^{* * *}\end{array}$ & $\begin{array}{l}-0.95 \% \\
(-1.32)\end{array}$ & \\
\hline$[0 ;+1]$ & $\begin{array}{c}-76.58 \% \\
(-38.28)^{* * *}\end{array}$ & $\begin{array}{c}-41.25 \% \\
(-26.59)^{* * *}\end{array}$ & $\begin{array}{c}-20.70 \% \\
(-13.38)^{* * *}\end{array}$ & $\begin{array}{l}-16.24 \% \\
(-21.41)^{* * *}\end{array}$ & $\begin{array}{l}-46.17 \% \\
(-36.00)^{* * *}\end{array}$ & $\begin{array}{l}-1.27 \% \\
(-1.74)\end{array}$ & \\
\hline$[0 ;+2]$ & $\begin{array}{c}-70.60 \% \\
(-28.81)^{* * *}\end{array}$ & $\begin{array}{l}-14.90 \% \\
(-7.84)^{* * *}\end{array}$ & $\begin{array}{l}-16.53 \% \\
(-8.72)^{* * *}\end{array}$ & $\begin{array}{c}-11.20 \% \\
(-12.07)^{* * *}\end{array}$ & $\begin{array}{c}-34.01 \% \\
(-21.66)^{* * *}\end{array}$ & $\begin{array}{l}0.20 \% \\
(0.23)\end{array}$ & \\
\hline \multicolumn{8}{|c|}{ Panel B: Abnormal volume of trading } \\
\hline-2 & $\begin{array}{c}0.92 \\
(1.23)\end{array}$ & $\begin{array}{l}-0.30 \\
(-0.45)\end{array}$ & $\begin{array}{c}0.70 \\
(1.22)\end{array}$ & $\begin{array}{c}-0.01 \\
(-0.02)\end{array}$ & $\begin{array}{c}0.44 \\
(0.83)\end{array}$ & $\begin{array}{c}-0.23 \\
(-0.64)\end{array}$ & 1.56 \\
\hline-1 & $\begin{array}{c}1.77 \\
(2.37)^{* * *}\end{array}$ & $\begin{array}{c}1.00 \\
(1.50)\end{array}$ & $\begin{array}{c}1.31 \\
(2.29)^{* * *}\end{array}$ & $\begin{array}{c}0.44 \\
(1.18)\end{array}$ & $\begin{array}{c}1.36 \\
(2.56)^{* * *}\end{array}$ & $\begin{array}{c}-0.02 \\
(-0.06)\end{array}$ & $3.23^{* * *}$ \\
\hline 0 & $\begin{array}{c}3.98 \\
(5.34)^{* * *}\end{array}$ & $\begin{array}{c}1.75 \\
(2.63)^{* * *}\end{array}$ & $\begin{array}{c}2.41 \\
(4.21)^{* * *}\end{array}$ & $\begin{array}{c}1.31 \\
(3.54)^{* * *}\end{array}$ & $\begin{array}{c}2.71 \\
(5.11)^{* * *}\end{array}$ & $\begin{array}{c}0.61 \\
(1.72)\end{array}$ & $4.92^{* * *}$ \\
\hline+1 & $\begin{array}{c}4.12 \\
(5.53)^{* * *}\end{array}$ & $\begin{array}{c}2.57 \\
(3.87)^{* * *}\end{array}$ & $\begin{array}{c}2.04 \\
(3.56)^{* * *}\end{array}$ & ${ }^{1.22}$ & $\begin{array}{c}2.91 \\
(5.48)^{* * *}\end{array}$ & $\begin{array}{c}0.38 \\
(1.06)\end{array}$ & $5.93^{* * *}$ \\
\hline+2 & $\begin{array}{c}3.36 \\
(4.50)^{* * *}\end{array}$ & $\begin{array}{c}2.91 \\
(4.38)^{* * *}\end{array}$ & $\begin{array}{c}2.21 \\
(3.86)^{* * *}\end{array}$ & $\begin{array}{c}1.28 \\
(3.46)^{* * *}\end{array}$ & $\begin{array}{c}2.82 \\
(5.33)^{* * *}\end{array}$ & $\begin{array}{c}0.51 \\
(1.44) \\
\end{array}$ & $5.42^{* * *}$ \\
\hline$[-2 ;-1]$ & $\begin{array}{c}2.68 \\
(2.54)^{* * *}\end{array}$ & $\begin{array}{c}-0.19 \\
(-0.20)\end{array}$ & $\begin{array}{c}1.91 \\
(2.36)^{* * *}\end{array}$ & $\begin{array}{c}0.43 \\
(0.82)\end{array}$ & $\begin{array}{c}1.80 \\
(2.39)^{* * *}\end{array}$ & $\begin{array}{c}-0.25 \\
(-0.50)\end{array}$ & \\
\hline$[0 ;+1]$ & $\begin{array}{c}8.10 \\
(7.68)^{* * *}\end{array}$ & $\begin{array}{c}4.14 \\
(4.41)^{* * *}\end{array}$ & $\begin{array}{c}6.49 \\
(8.02)^{* * *}\end{array}$ & $\begin{array}{c}2.53 \\
(4.83)^{* * *}\end{array}$ & $\begin{array}{c}5.62 \\
(7.49)^{* * *}\end{array}$ & $\begin{array}{c}0.99 \\
(1.96)^{* * *}\end{array}$ & \\
\hline$[0 ;+2]$ & $\begin{array}{c}11.46 \\
(8.87)^{* * *}\end{array}$ & $\begin{array}{c}8.01 \\
(6.97)^{* * *}\end{array}$ & $\begin{array}{c}10.06 \\
(10.14)^{* * *}\end{array}$ & $\begin{array}{c}3.81 \\
(5.94)^{* * *}\end{array}$ & $\begin{array}{c}8.45 \\
(9.19)^{* * *}\end{array}$ & $\begin{array}{c}1.50 \\
(2.43)^{* * *}\end{array}$ & \\
\hline
\end{tabular}

This table presents the abnormal equity returns (Panel $A$ ) and volume of trading (Panel $B$ ) for a five-day period surrounding the day $t=0$ (September 14th, 2007). The abnormal returns are derived from the onefactor market model estimated over the period $[-260 ;-11]$ using FTSE All-Share benchmark index. As the abnormal returns are in fact prediction errors, the standard deviation estimator used in the definition of the test statistic was adjusted in order not to overstate the significance levels (the correction factor is defined in Mikkelson and Partch (1988, p. 122, corrected formula 3). Also, the statistical tests were adjusted to avoid the misspecification problems due to extreme clustering and cross-correlation of security returns in the event period (see Brown and Warner, 1985, pp. 7-8). The abnormal volume of trading metric is defined as the difference between the observed turnover ratio and the median turnover ratio through the estimation window. The sample of UK listed banks was partitioned into two sub-samples: "Mortgage banks" (viz. Alliance \& Leicester, Bradford \& Bingley, and Northern Rock) and "Other banks" (Barclays, HBOS, HSBC, Lloyds, Royal Bank of Scotland, and Standard Chartered). We also report the mean cumulative abnormal returns $($ Panel $A)$ and trading volume $($ Panel $B)$ computed over various event windows: $[-2 ;-1],[0 ;+1]$, and $[0 ;+2]$. The last column reports the $t$-statistics for the difference in average abnormal returns $($ Panel $A)$ and trading volume (Panel $B$ ) between the two sub-samples of banks.

$* * *$ indicates statistical significance at the $1 \%$ level 
Figure 1. Excess of 3-mth $f$ Libor over UK base rates

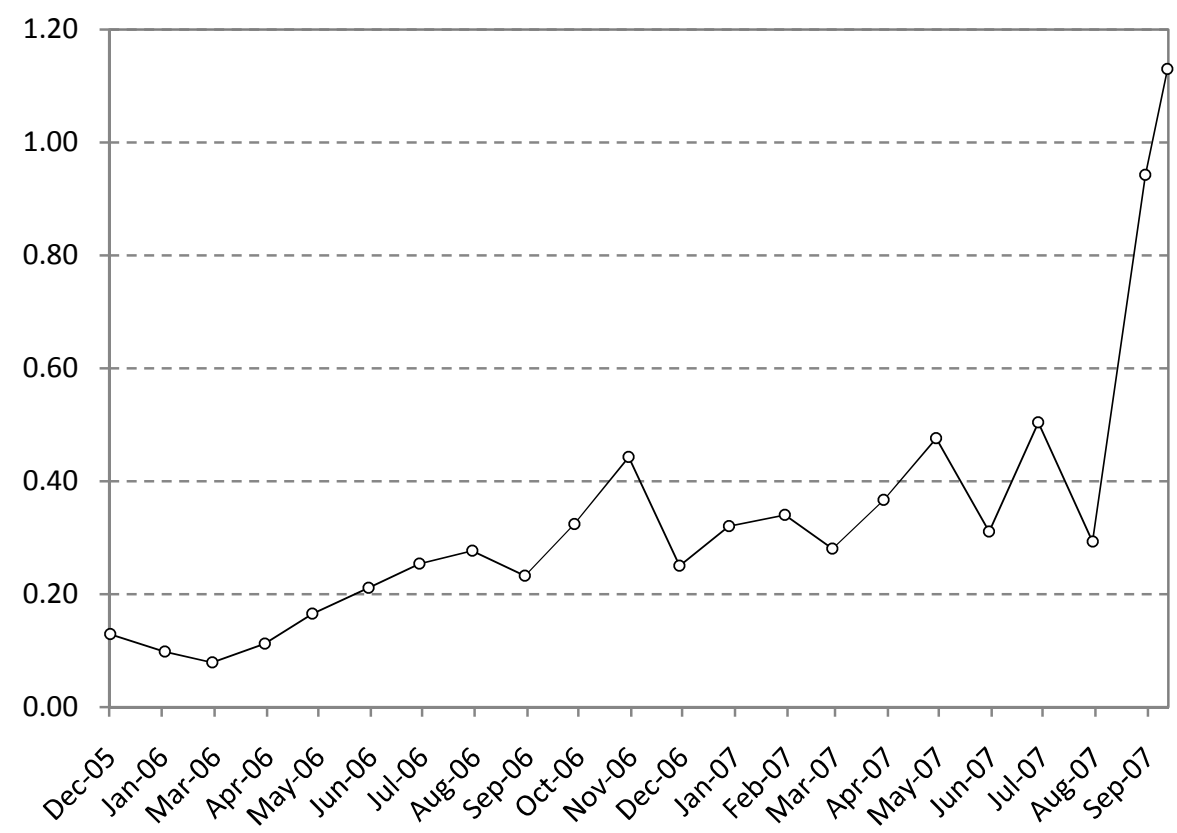

Figure 2. UK mortgage banks' equity prices, rebased value (\% of $01 / 01 / 07$ value)

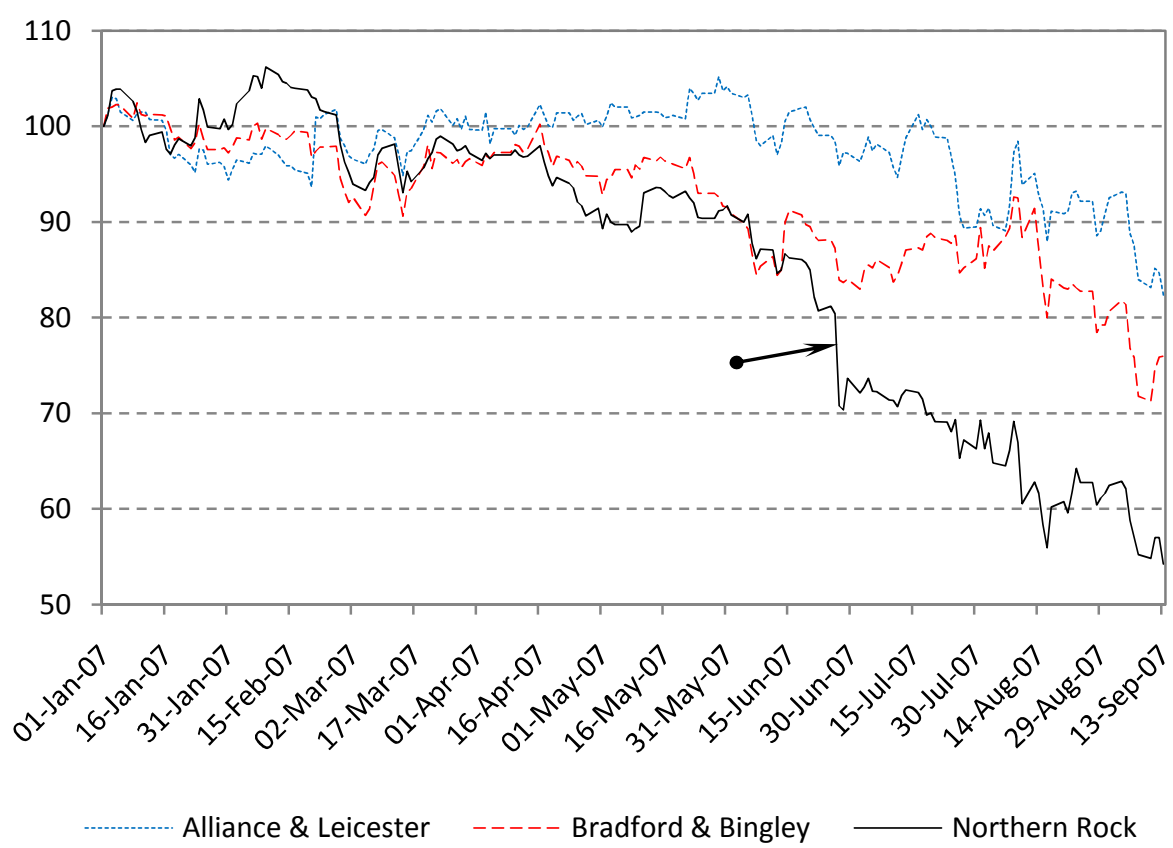


Figure 3. UK mortgage banks' equity prices, rebased value (\% of 01/06 value)

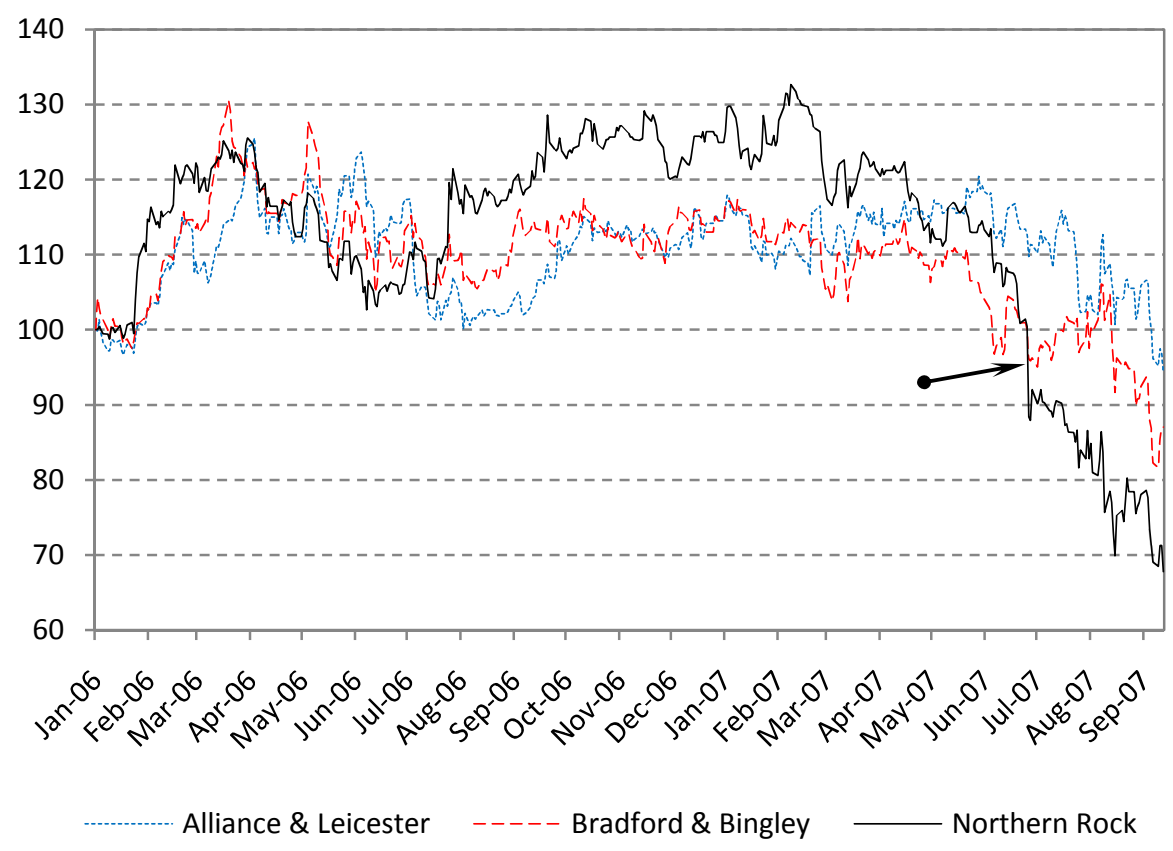

Figure 4. All UK banks' equity prices, rebased value (\% price in 01/06)

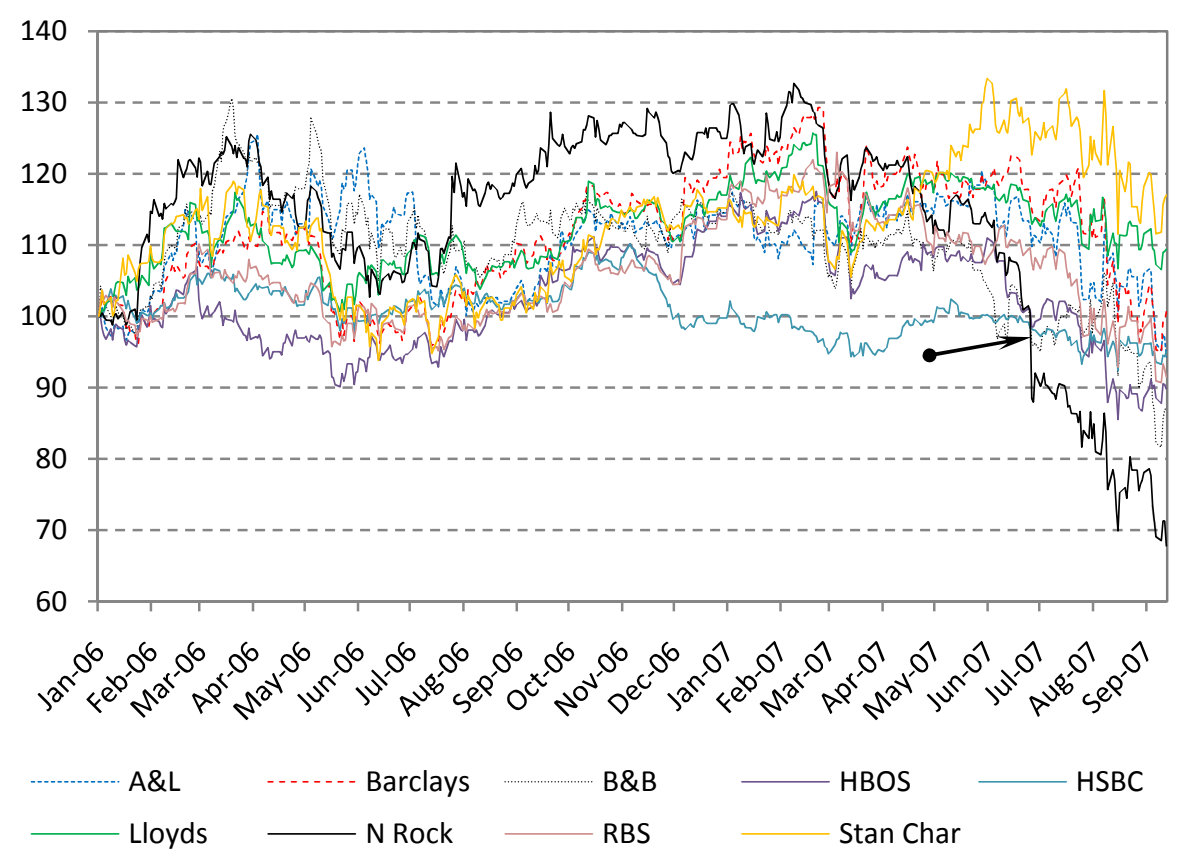


Figure 5. UK mortgage banks' equity trading volume (10 day MA)

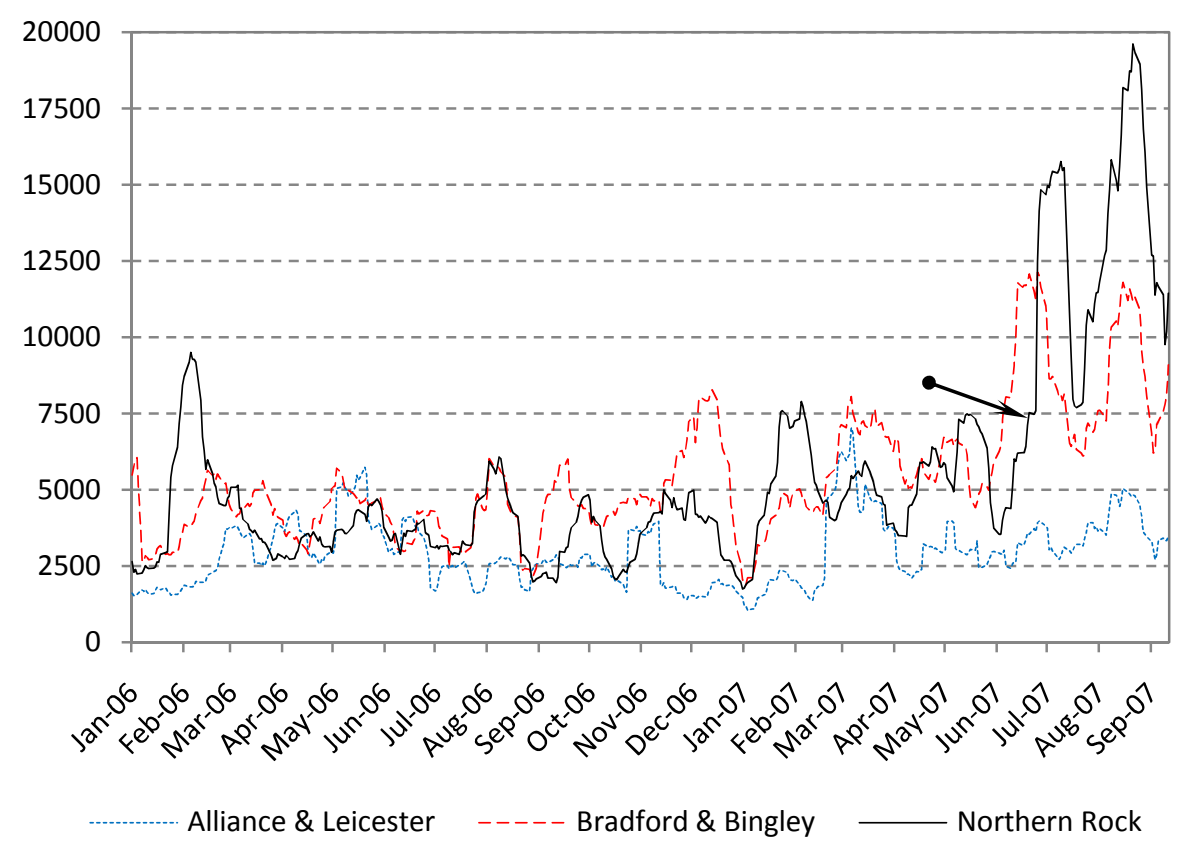

Figure 6. UK mortgage banks' cumulative weekly return difference (\%) with portfolio of other UK banks

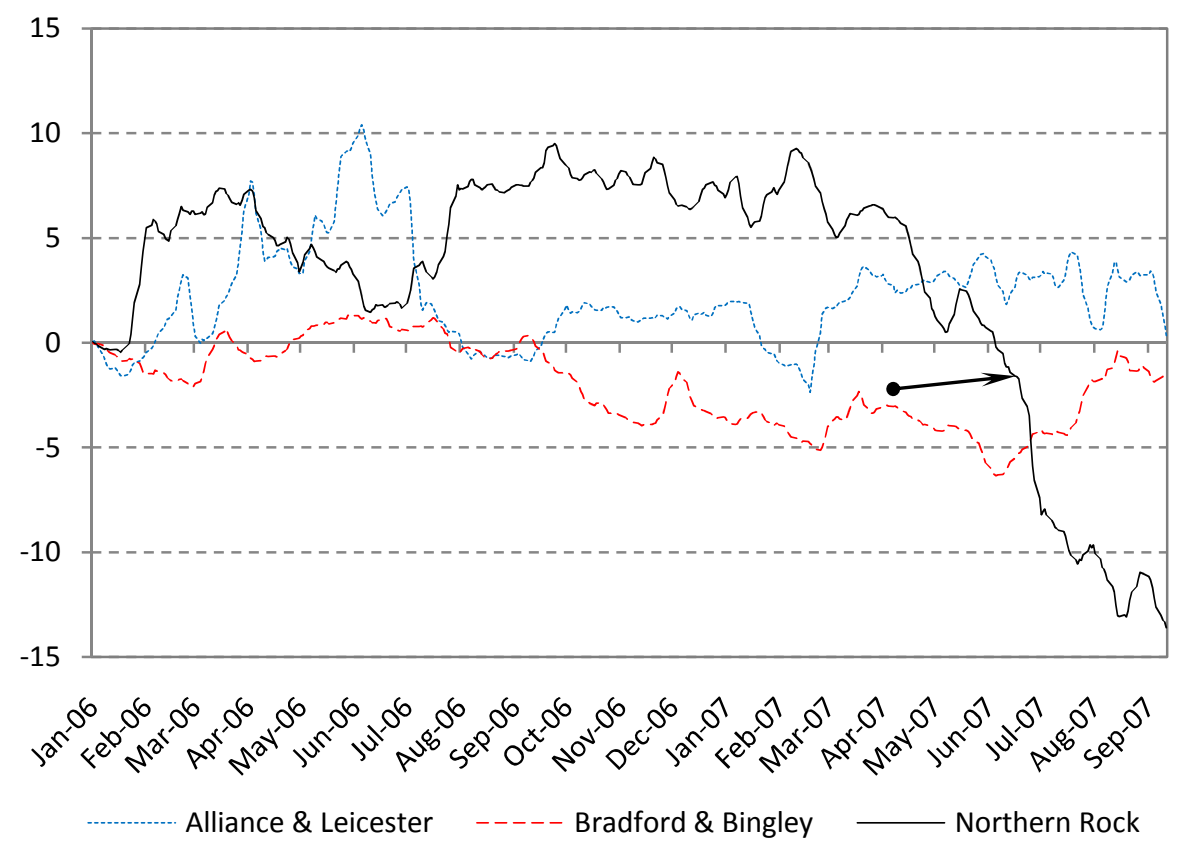


Figure 7. Time evolution of the Distance-to-Default (DD) indicator for the nine UK listed banks

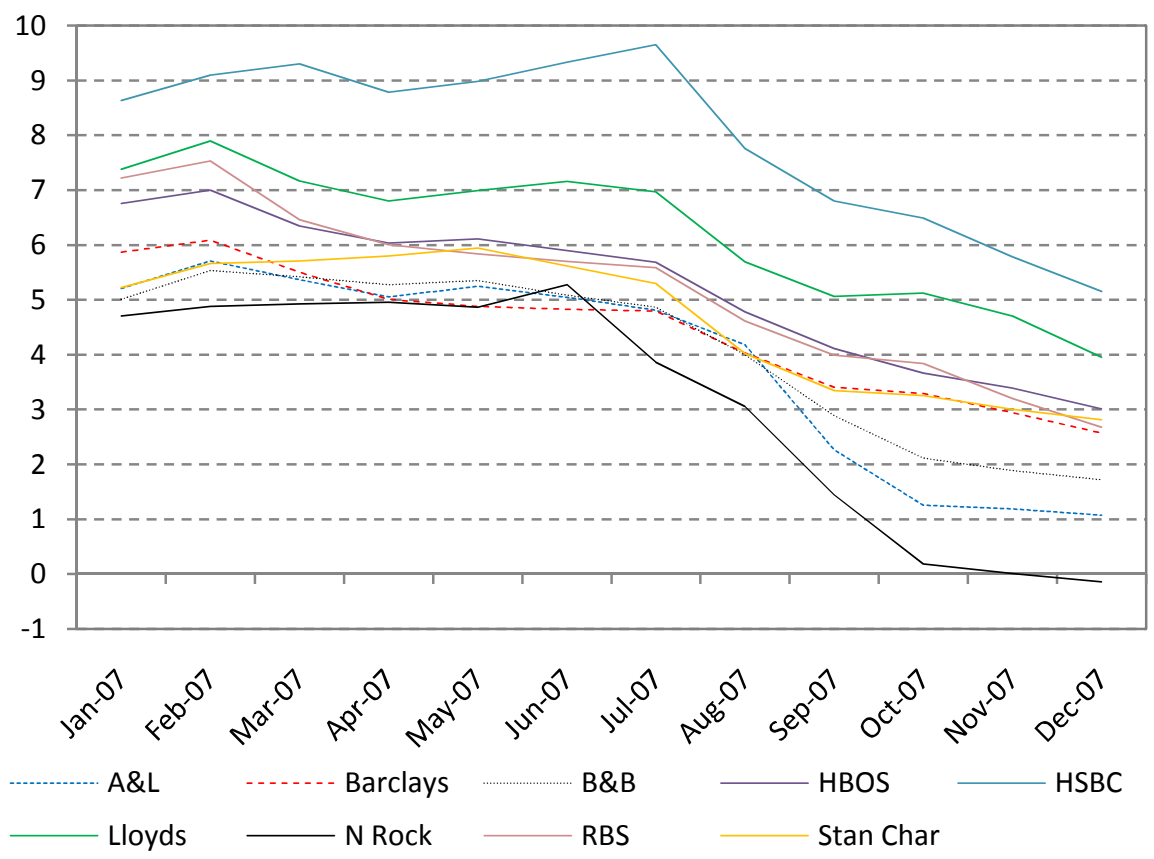

Figure 8. Time evolution of Implied Idiosyncratic Volatilities (IIV) of UK listed banks' stocks

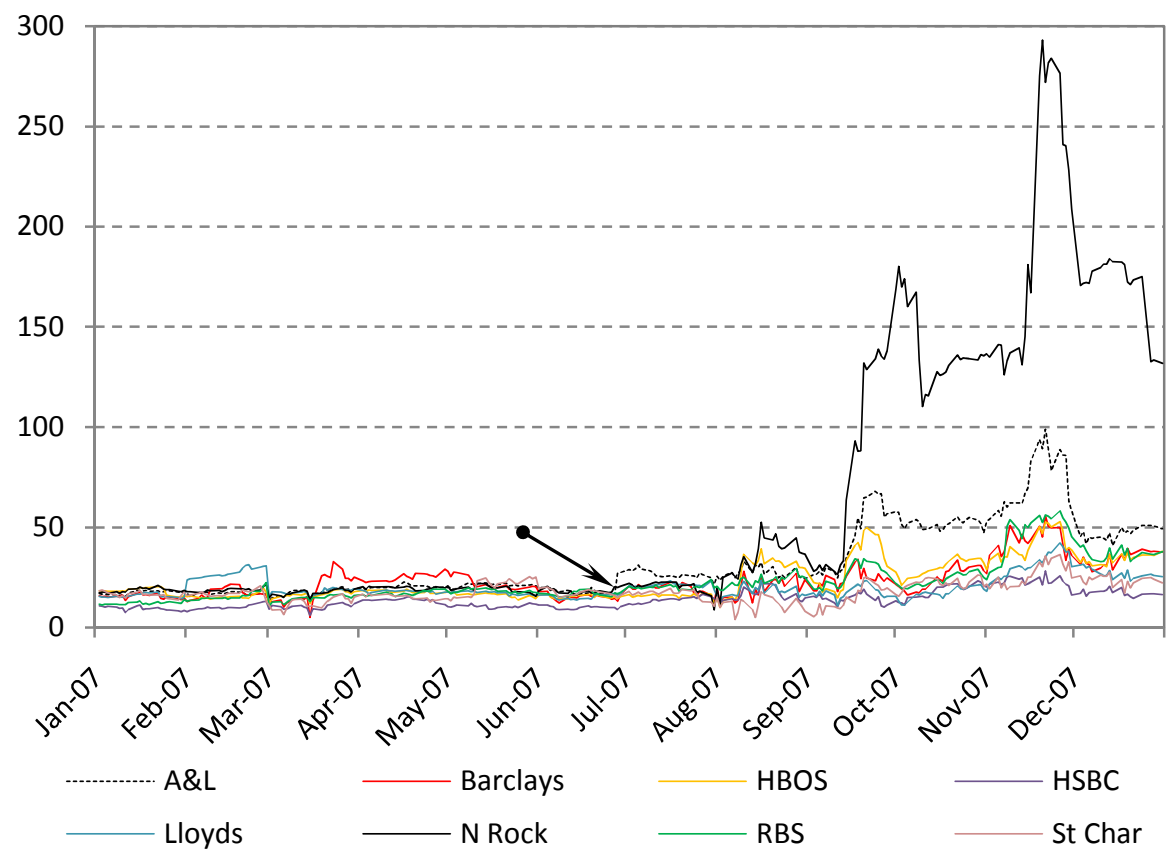


Figure 9. UK mortgage banks' SND spreads (bps), 10y and less

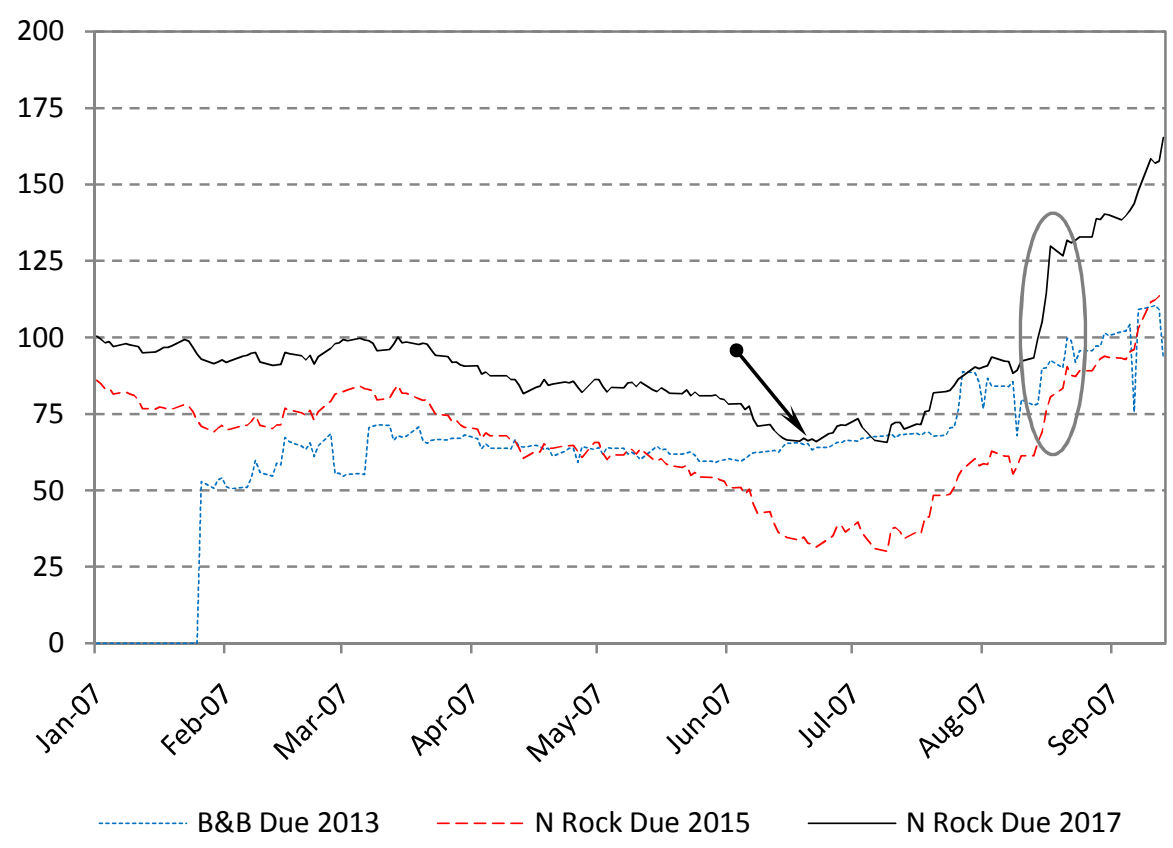

Figure 10. UK mortgage banks' SND spreads (bps), 10y and more

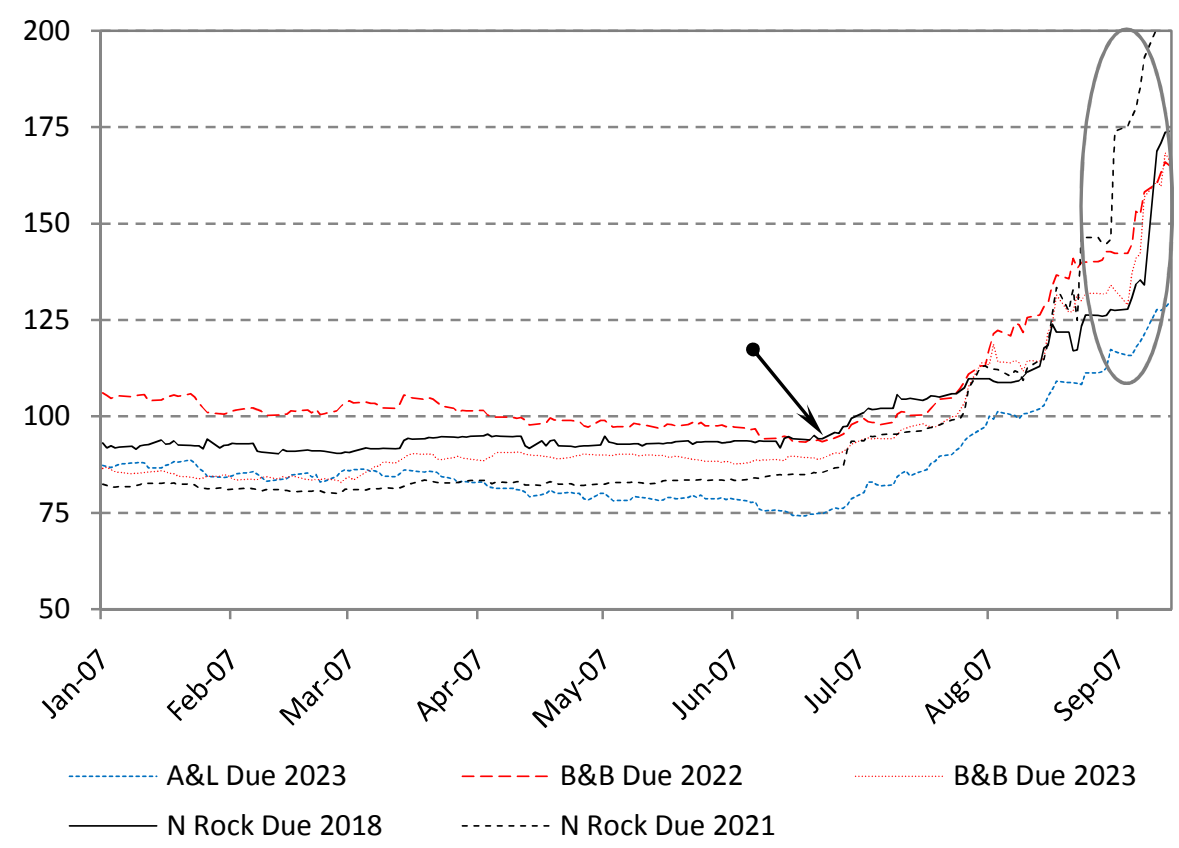


Figure 11. Selected large UK banks' SND spreads (bps), 10y and less

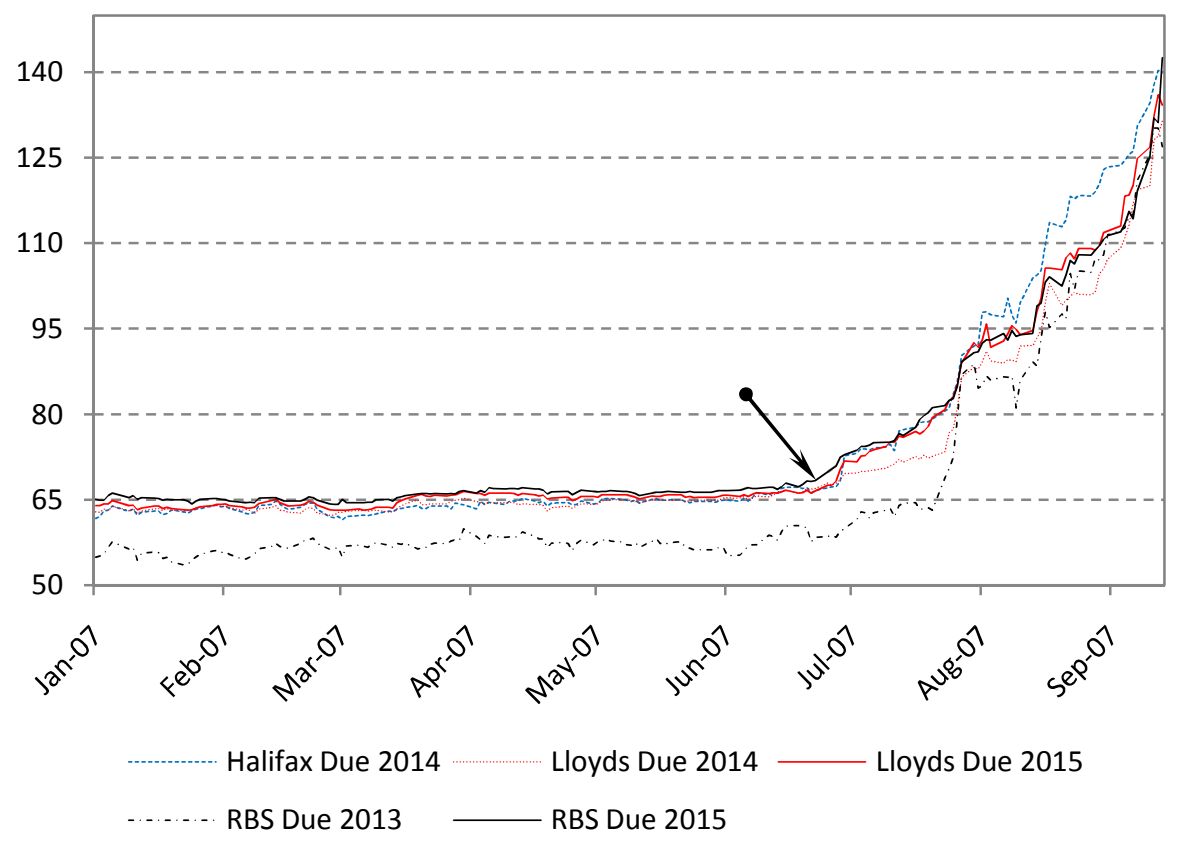

Figure 12. Selected large UK banks' SND spreads (bps), 10y and more

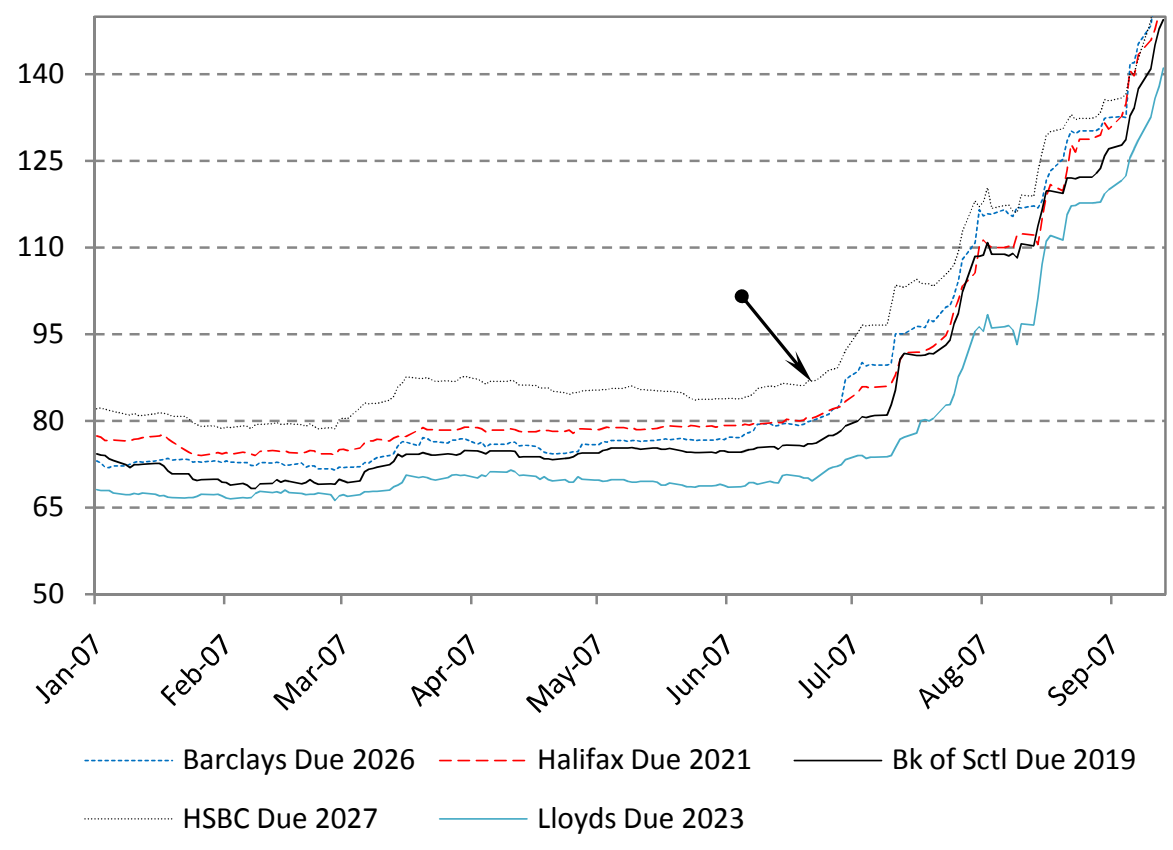


Figure 13. UK mortgage banks' CDS spreads (bps), 1y Senior

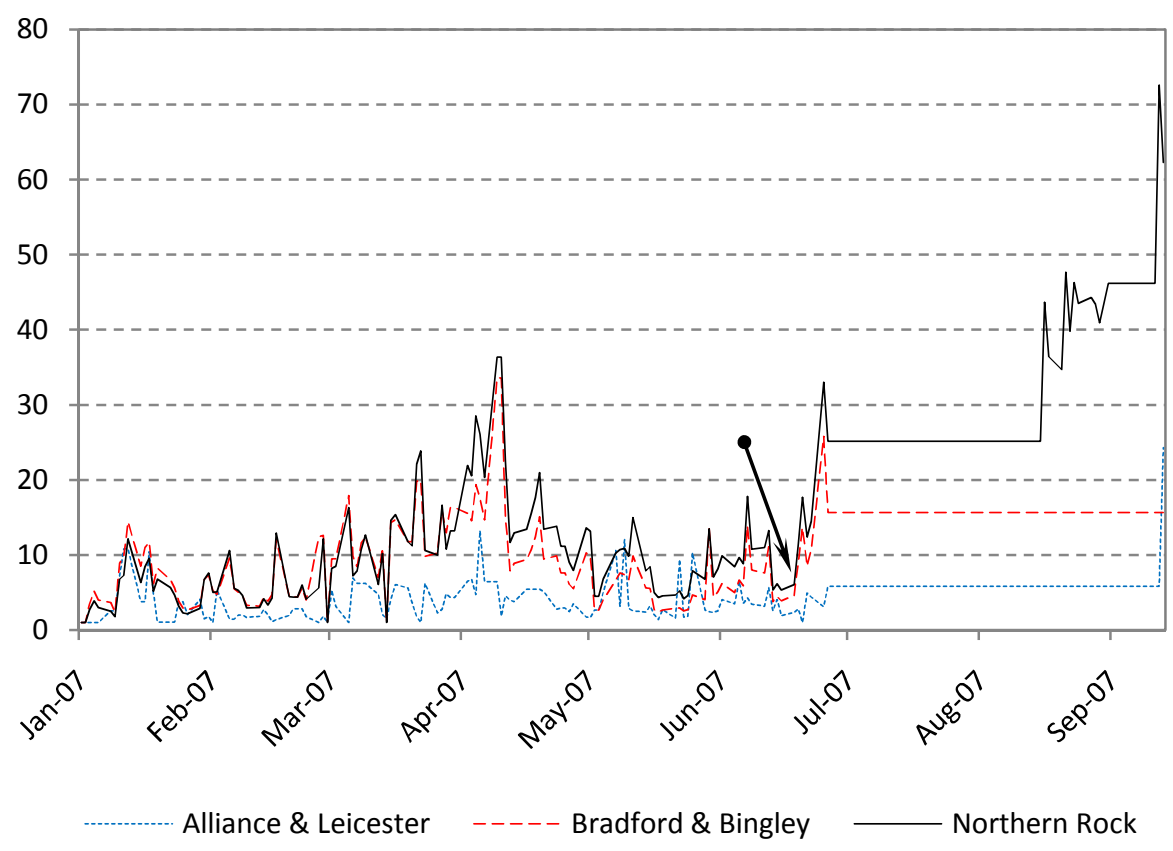

Figure 14. UK banks' CDS spreads (bps), 1y Senior

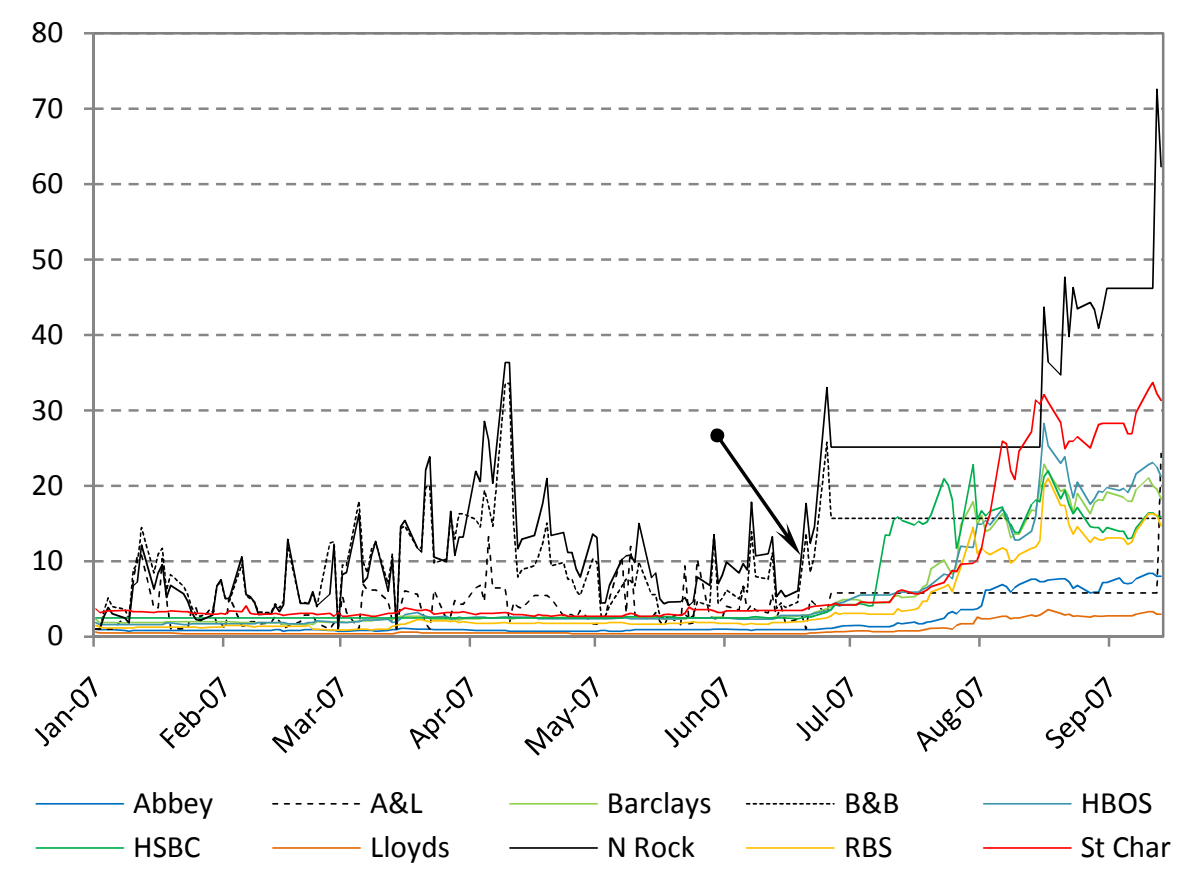


Figure 15. UK mortgage banks' CDS spreads (bps), 5y Senior

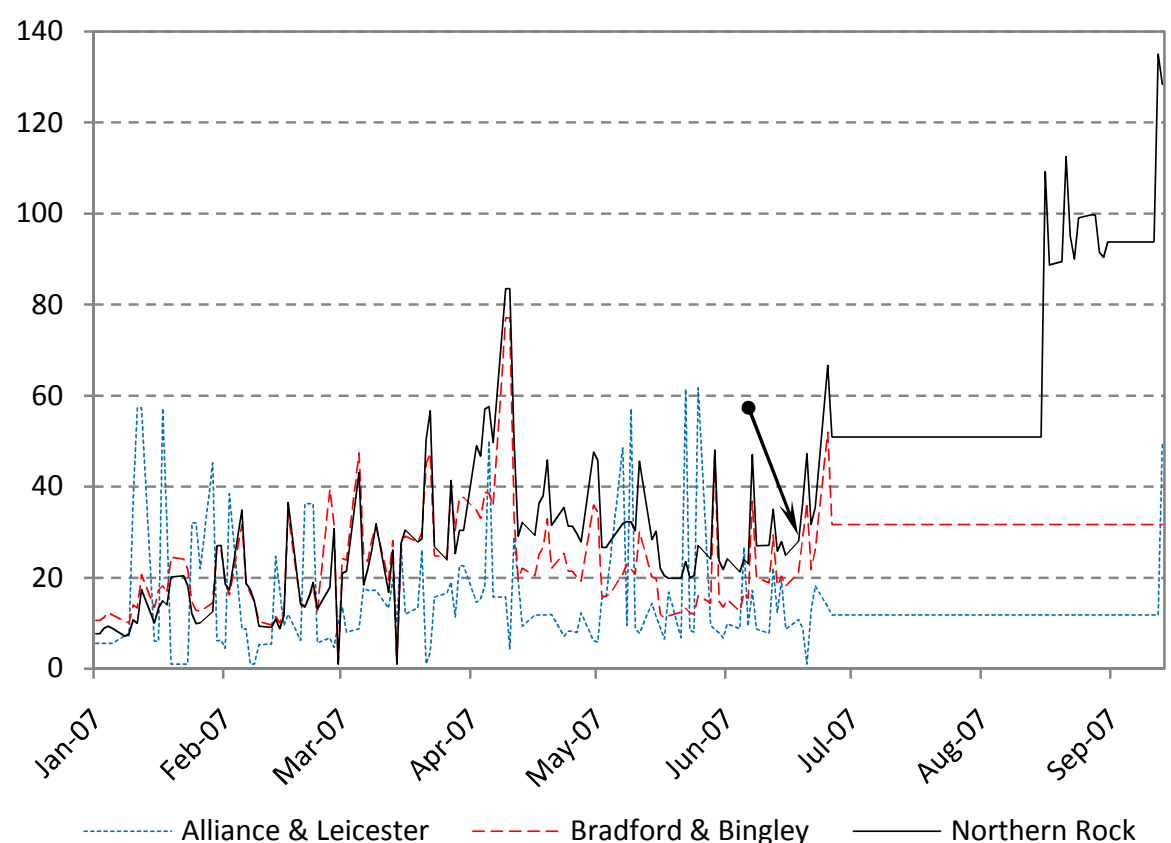

Figure 16. UK banks' CDS spreads (bps), 5y Senior

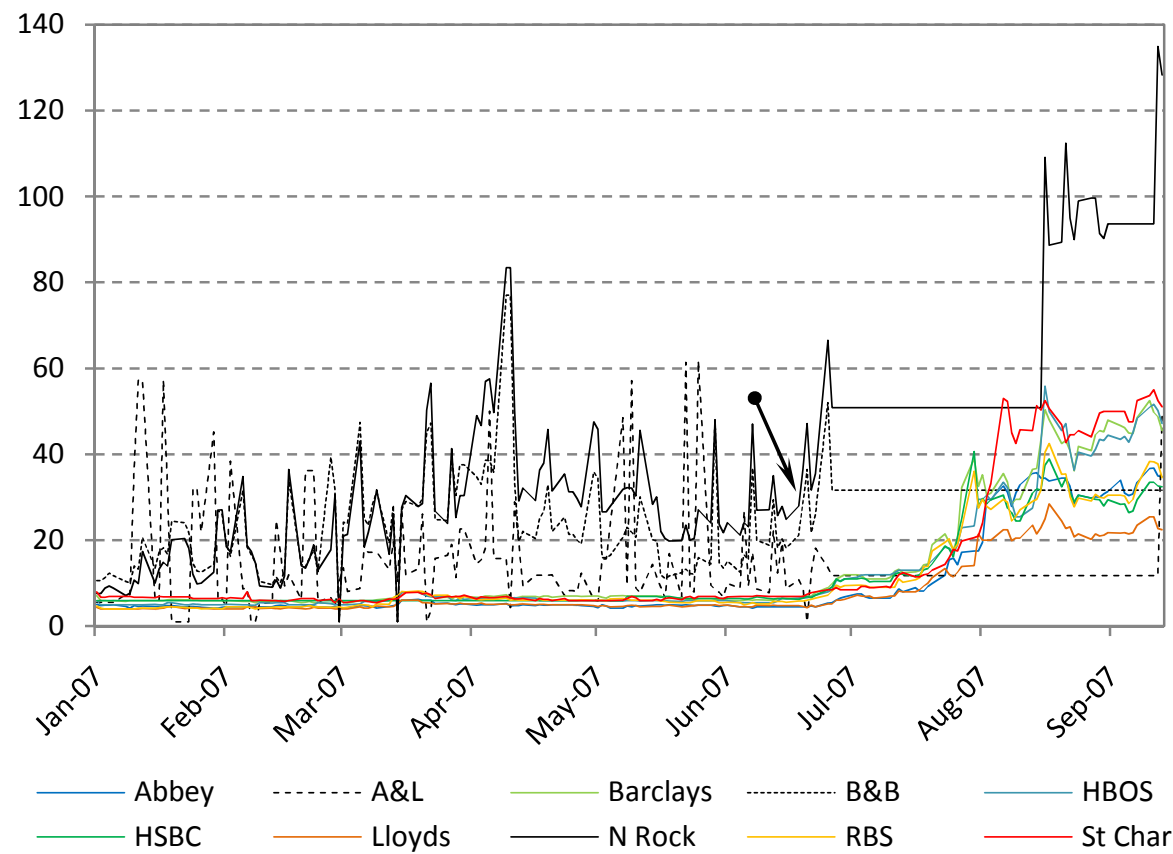

